\title{
Reengineering the Tumor Microenvironment to Alleviate Hypoxia and Overcome Cancer Heterogeneity
}

\author{
John D. Martin, ${ }^{1}$ Dai Fukumura, Dan G. Duda, Yves Boucher, and Rakesh K. Jain \\ Edwin L. Steele Laboratories, Department of Radiation Oncology, Massachusetts General Hospital \\ and Harvard Medical School, Boston, Massachusetts 02114 \\ Correspondence: jain@steele.mgh.harvard.edu
}

Solid tumors consist of cancer cells and stromal cells, including resident and transiting immune cells-all ensconced in an extracellular matrix (ECM)—nourished by blood vessels and drained by lymphatic vessels. The microenvironment constituents are abnormal and heterogeneous in morphology, phenotype, and physiology. Such irregularities include an inefficient tumor vascular network comprised of leaky and compressed vessels, which impair blood flow and oxygen delivery. Low oxygenation in certain tumor regions—or focal hypoxia-is a mediator of cancer progression, metastasis, immunosuppression, and treatment resistance. Thus, repairing an abnormal and heterogeneous microenvironment-and hypoxia in particular - can significantly improve treatments of solid tumors. Here, we summarize two strategies to reengineer the tumor microenvironment (TME) — vessel normalization and decompression - that can alleviate hypoxia. In addition, we discuss how these two strategies alone and in combination with each other-or other therapeutic strategies-may overcome the challenges posed by cancer heterogeneity.

$\mathrm{O}$ rgans are composed of parenchyma, which is the tissue component that serves the organ's main function, and stroma, which is the other component that structurally and functionally supports the parenchyma. Cancer cells arise from oncogenic mutations in the DNA of either parenchymal or stromal cells. As these malignant cells proliferate, they recruit nearby nonmalignant cells into collaborative processes to foster a microenvironment conductive for local growth and metastasis to distant organs. This collection of cancer cells interacting with host cells forms an abnormal organ-like struc- ture (Fig. 1A) in which cancer cells are parenchyma and the microenvironment is stroma.

Cancer cells, with diverse and interacting subpopulations (Marusyk et al. 2014; Tabassum and Polyak 2015), are heterogeneous at multiple levels: between patients, but also within a single tumor, and between primary tumors and their metastases (Naxerova et al. 2014; Naxerova and Jain 2015). Cancer cells recruit endothelial cells (ECs), fibroblasts, and immune cells as stromal elements, and these stromal constituents are also morphologically, phenotypically, and functionally heterogeneous (Hida et al. 2004; Sugi-

${ }^{1}$ Present address: Department of Bioengineering, The University of Tokyo, Tokyo 113-8656, Japan.

Editors: Charles Swanton, Alberto Bardelli, Kornelia Polyak, Sohrab Shah, and Trevor A. Graham

Additional Perspectives on Cancer Evolution available at www.perspectivesinmedicine.org

Copyright (C) 2016 Cold Spring Harbor Laboratory Press; all rights reserved; doi: 10.1101/cshperspect.a027094

Cite this article as Cold Spring Harb Perspect Med 2016;6:a027094 
J.D. Martin et al.

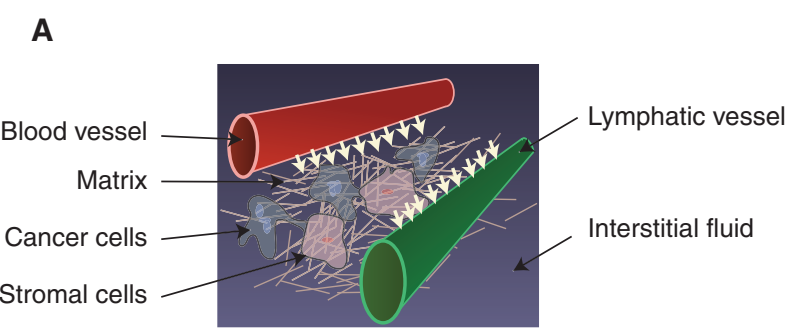

B

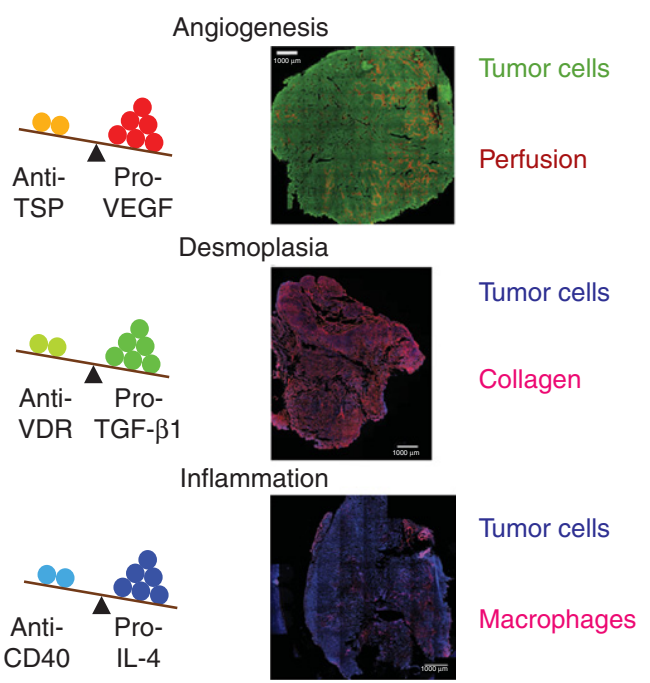

Figure 1. Solid tumors are composed of not only malignant tumor cells but also abnormal stroma resultant from dysregulated angiogenesis, desmoplasia, and inflammation. (A) Cancer cells coopt nonmalignant host cells, including fibroblasts, a variety of immune cells, and blood and lymphatic vascular cells embedded in a densely packed extracellular matrix (ECM) with a harsh molecular, metabolic, and physical microenvironment that supports tumor progression and resists therapy and host immune response. (From Jain 2013; adapted, with permission, from the author.) (B) Activated and dysregulated angiogenesis, desmoplasia, and inflammation, which result from an imbalance of positive and negative regulators of these processes, are responsible for the heterogeneous tumor microenvironment (TME). Primary stimulators of angiogenesis, desmoplasia, and inflammation include vascular endothelial growth factor (VEGF), transforming growth factor $\beta 1$ (TGF- $\beta 1$ ), and certain interleukins (e.g., IL-4), respectively. Primary regulators of angiogenesis, desmoplasia, and inflammation include thrombospondins (TSPs), vitamin D receptor (VDR), and CD40 (a member of tumor necrosis factor receptor superfamily), respectively. (Images based on data from Huang et al. 2012 and Incio et al. 2015.)

moto et al. 2006; Movahedi et al. 2008; Palumbo et al. 2015). Furthermore, the interaction between cancer and stromal cells stimulates the production of abnormal vasculature (Fukumura et al. 1998; Jain 2014), fibrotic tissue (Apte et al. 2004; Bailey et al. 2008), and immune factors (Lin et al. 2001; Robinson et al. 2003), without promoting the maturation of these components. These processes collaborate to foster an abnormal vascular network charac- terized by leaky and compressed blood and lymphatic vessels, which lead to creation of hypoxic regions in the tumors (Jain 2014).

In healthy tissue, vessels are uniformly distributed by distances determined by the ability of each vessel to supply oxygen and nutrients to its surrounding volume of tissue (Baish et al. 2011). In tumors, leakiness and compression of vessels leave large volumes of tissue without blood flow (Baish et al. 2011; Stylianopoulos 
and Jain 2013). As a result, most tumors have hypoxic regions. Hypoxia promotes abnormal angiogenesis (Pugh and Ratcliffe 2003), desmoplasia (Spivak-Kroizman et al. 2013), and inflammation (Facciabene et al. 2011) —all contributing to tumor progression and treatment resistance (Jain 2014; Whatcott et al. 2015b). Thus, once an abnormal vasculature develops (see online Movie 1 at www.cshperspectives .cshlp.org) and leads to a hypoxic microenvironment, a vicious cycle promoting cancer progression and heterogeneity sets in. Our hypothesis is that repairing these two abnormalities of tumor vessels-leakiness and compressionwill alleviate hypoxia, thereby exiting the vicious cycle contributing to the tumor heterogeneity, delaying progression, and improving treatment outcomes for cancer patients.

\section{TUMOR MICROENVIRONMENT}

\section{Abnormal Cellular Components}

Cancer cells reside in and orchestrate their abnormal microenvironment (Fig. 1A). They harbor mutations that enable them to initiate and drive tumor progression. Furthermore, cancer cells are genetically, epigenetically, and phenotypically diverse, with subclonal populations even within a single tumor (Tabassum and Polyak 2015). As a consequence, different regions within a tumor feature unique levels of differentiation, proliferation, vascularity, inflammation, immunosuppression, and invasiveness. These subpopulations interact, as minor subpopulations can drive the proliferation of subpopulations with rapid growing potential, promoting both disease progression and competition (Marusyk et al. 2014). These genetic differences between cancer cell subpopulations within a single tumor might reduce the efficacy of targeted therapies (Bedard et al. 2013), which may only be active against limited subpopulations, and these subpopulations may not be accessible to blood-borne therapies because of heterogeneous blood flow.

Adding to the heterogeneity of cancer cells, signals from stromal cells and extracellular matrix (ECM) components can also promote and maintain cancer stem/stem-like cells (CSCs) (Lu et al. 2012; Chanmee et al. 2014; Chen et al. 2014a; Whatcott et al. 2015b). CSCs represent a population of cancer cells thought to be responsible for tumor initiation and progression (Magee et al. 2012). CSCs can also differentiate through hypoxia-mediated mechanisms into cells that may serve the same functions as coopted host cells, such as ECs and cancerassociated fibroblasts (CAFs) (Ricci-Vitiani et al. 2010; Wang et al. 2010; Soda et al. 2011).

ECs line the luminal surface of blood vessels, and typically are quiescent except during development, wound healing, and disease (Carmeliet and Jain 2011a). Quiescent ECs in tumors are activated by angiogenic factors such as vascular endothelial growth factor (VEGF) produced by hypoxic cancer and stroma cells (Shweiki et al. 1992), resulting in sprouting angiogenesis (Gerhardt et al. 2003), which is the process through which new vessels are formed from existing vessels. In tumors, signaling is tipped in favor of proangiogenic signaling at the expense of antiangiogenic and vessel maturing factors such as thrombospondins, resulting in abnormalities in tumor vasculature (Fig. 1B). Angiogenic intratumoral ECs have distinctive gene expression profiles and luminal cell-surface receptors compared with quiescent cells (Croix et al. 2000). The morphology of tumor ECs is abnormalirregular and disorganized. They have weaker interendothelial junctions and more "transendothelial channels" - vesiculo-vascular organelles-structural substrates of increased vessel leakiness (Goel et al. 2011). Lymphatic ECs line the luminal surface of lymphatic vessels, which drain excess fluid from tissues (Alitalo 2011; Kesler et al. 2013; Padera et al. 2016). In tumors, normal cell-surface markers of lymphatic ECs are expressed in both blood and lymphatic vessels, underscoring the abnormality of these cells (Padera et al. 2002; Jain 2014).

Perivascular cells, such as pericytes and vascular smooth muscle cells, support the structure, quiescence, and function of ECs in normal tissues through physical interaction and paracrine/juxtacrine signaling (Carmeliet and Jain 2011a). Pericytes have finger-like structures that wrap around vessels and share with ECs the 
J.D. Martin et al.

basement membrane that anchors vessels (Jain 2003). However, in tumors, pericytes are abnormally shaped and loosely attached to ECs, if not altogether absent (Goel et al. 2011). Indeed, the detachment of perivascular cells is a prerequisite for angiogenesis. Once angiogenesis is initiated, these cells in turn support angiogenesis, guide EC sprouting, and sensitize activated ECs to angiogenic stimuli (Raza et al. 2010).

There is a significant population of CAFs and/or stellate cells (a type of stromal cell), depending on the host organ, that produce and maintain the ECM, which supports the epithelial tissue in carcinomas (Ronnov-Jessen et al. 1996; Tlsty and Coussens 2006; Whatcott et al. 2015b). These cells are activated as a result of an imbalance of pro- and antifibrotic signaling (Fig. 1B). For example, fibroblasts can be activated through transforming growth factor $\beta 1$ (TGF- $\beta 1$ ) signaling, whereas hepatic and pancreatic stellate cells (HSCs and PSCs) can become quiescent via vitamin $\mathrm{D}$ receptor (VDR) stimulation or angiotensin-II-receptor-1 blockade (Chauhan et al. 2013; Ding et al. 2013; Sherman et al. 2014). The increased activity/proliferation of these cells in tumors produces a desmoplastic reaction rich in collagen fibers, hyaluronan, and other ECM molecules (Ohlund et al. 2014). The cross talk between cancer cells, HSCs/PSCs/CAFs and other cells of the tumor microenvironment (TME) regulates the expression of cytokines and exosomes that promote desmoplasia, cancer cell proliferation and stemness, angiogenesis, inflammation/immunosuppression, invasion, and metastasis (Erez et al. 2010; Kraman et al. 2010; Chen et al. 2014a; Haqq et al. 2014; Ohlund et al. 2014; Albrengues et al. 2015). There is a large diversity in the origin, phenotype, and function of CAFs (Ohlund et al. 2014; Ishii et al. 2015; Singhal et al. 2016). Recent studies have identified CAF subpopulations that promote tumor progression via multiple mechanisms and whose presence in tumors correlates with a poor outcome in cancer patients (Albrengues et al. 2014; Haqq et al. 2014; ScherzShouval et al. 2014).

Immune cells participate in two systems of immune response: innate and adaptive. The in- nate response, of which macrophages in the tumor are particularly important, is nonspecific and defends the host from infection. Resident macrophages originate during embryonic development and proliferate locally in the host tissues, whereas macrophages recruited from the circulation differentiate from myeloid precursor cells. Macrophages recruit other innate immune cells to clear waste and debris from dead cells and activate the adaptive response. These cells act in concert with physical barriers to pathogens. Dendritic cells act in both systems as early phagocytic cells and major antigen-presenting cells. The adaptive immune response featuring $\mathrm{T}$ and $\mathrm{B}$ lymphocytes recognizes foreign pathogens, generates a specific response to eliminate a given pathogen, and develops memory to quickly respond to the pathogen in the future.

The cells of the adaptive immune response can promote the recruitment of innate response cells to support or inhibit tumor progression depending on cues from the TME (DeNardo et al. 2010). Indeed, macrophages are plastic, as when they are exposed to cytokines in the TME they support tumor progression, whereas other stimuli induce them to attack the tumor (Coussens et al. 2013). In contrast to normal tissues, in which inflammation resolves itself, the balance of stimuli is tipped in favor of inflammation and immune suppression (Fig. 1B). One such protumor stimulus are certain interleukins such as IL-4, which promotes a protumor macrophage phenotype (DeNardo et al. 2009, 2011; Incio et al. 2016a), whereas agonism of the immune stimulatory receptor CD40 (Beatty et al. 2011) can induce an antitumor macrophage phenotype. TGF- $\beta 1$, which was discussed above as a profibrosis factor, also suppresses antitumor immune response (Wrzesinski et al. 2007; Pickup et al. 2013; Papageorgis and Stylianopoulos 2015). The cells of the innate immune response involved in wound healing express mitogenic, angiogenic, and stromal growth factors, as well as matrix remodeling enzymes, underscoring the interrelationship between inflammation, angiogenesis, and desmoplasia (Mantovani 2010; Incio et al. 2016b). The collaboration of the cellular components to 
induce unchecked stimulation of inflammation, angiogenesis, and desmoplasia converges at the tumor vasculature, which becomes morphologically, phenotypically, and physiologically heterogeneous.

\section{Abnormal Vessels and Intratumoral Pressure}

In normal organs, blood vessels supply tissues with oxygen and nutrients, whereas lymphatic vessels drain excess interstitial fluid. Blood flows to tissues through arteries, which branch within tissues into smaller order arterioles until becoming capillaries, and then converging to larger order venules, and, finally, returning through veins to the heart. Capillaries are the smallest size vessels and comprise the majority of blood vessels in the body. The capillary wall is where the exchange between blood and tissues takes place. Capillaries are often straight and parallel vessels with uniform spacing, such that tissue is evenly supplied with oxygen. The uniform geometry and topology of capillaries are assumptions of the Krogh model, which describes oxygen transport down the length and along the radii of normal capillaries out to the surrounding tissue. As the tumor microvessels are tortuous and irregularly spaced, they do not match the assumptions of the Krogh model and leave some regions inadequately supplied with oxygen (Jain 1988; Baish et al. 2011).

Tumor vessels are heterogeneous (Nagy et al. 2010), and many are hyperpermeable (Fig. 2A) (Yuan et al. 1994; Nagy et al. 2008; Chauhan et al. 2012). In their walls, there are interendothelial openings and transendothelial channels, resulting in a wide range of pore sizes (Hobbs et al. 1998; Hashizume et al. 2000). The hyperpermeability of tumor vessels allows plasma to flow to the interstitial space, thereby increasing the hematocrit and making blood in vessels more viscous, which reduces vascular perfusion (Jain 1988; Sevick and Jain 1989; Netti et al. 1996). Moreover, lymphatic vessels are compressed and not functional in tumors, so the excess plasma proteins and fluid in the interstitial space cannot be drained. As a result, in contrast to most normal tissues, the interstitial fluid pressure (IFP) is elevated inside solid tumors, and then it drops precipitously at the tumor periphery or surrounding normal tissue (Jain et al. 2007). In fact, because of the lack of permselectivity of tumor vessels, the microvascular pressure (MVP) and IFP are approximately equal (Boucher and Jain 1992). Thus, the transvascular pressure gradient is close to zero, which diminishes the bulk transport of blood-borne molecules from the blood into the interstitium (Boucher et al. 1990; Boucher and Jain 1992). Furthermore, the communication between vascular and interstitial fluid reduces intravascular blood flow by eliminating the pressure drop along the length of the vessel and shuts off downstream vessels (Netti et al. 1996; Baish et al. 1997). Thus, vessel leakiness reduces the function of vessels by reducing blood flow via two mechanisms and abrogating bulk transport across the vessel wall and through the interstitium. As a result, leaky vessels supply a smaller volume of tissue with nutrients and drugs than normal vessels (Fig. 2B).

Vascular compression is a phenomenon unrelated to leakiness (Fig. 2C), and is thought to result from solid stress buildup within the TME (Jain 1988). IFP has been ruled out as a cause of vessel collapse when IFP was discovered to be driven by MVP (Boucher and Jain 1992). In vivo studies showing that killing proliferating cells in tumors could decompress vessels (Griffon-Etienne et al. 1999; Padera et al. 2004) indicated that solid tumor components play a key role in vascular collapse. More direct evidence came from ex vivo measurements in freshly excised mouse and patient tumors (see online Movie 2 at www.cshperspectives.cshlp.org), which confirmed the presence of residual solid stress (Stylianopoulos et al. 2012). These data showed that cancer cells and fibroblasts generate stress-presumably through proliferation and contraction forces (Orimo et al. 2005; ZlotekZlotkiewicz et al. 2015). They also showed that solid stress is stored as strain energy in the ECM, of which collagen fibers and hyaluronan collaborate to transmit the strain energy as solid stress to compress blood and lymphatic vessels (Stylianopoulos et al. 2012, 2013; Chauhan et al. 2013; Jain et al. 2014). 
A

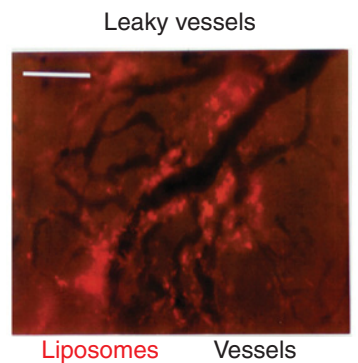

Liposomes Vessels
B

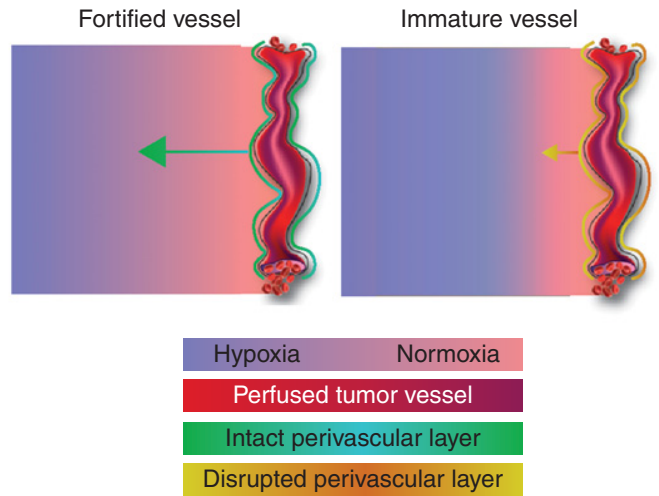

D

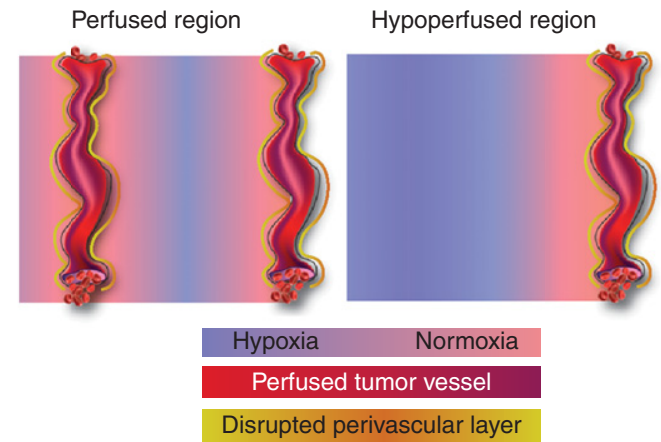

Disrupted perivascular layer

E
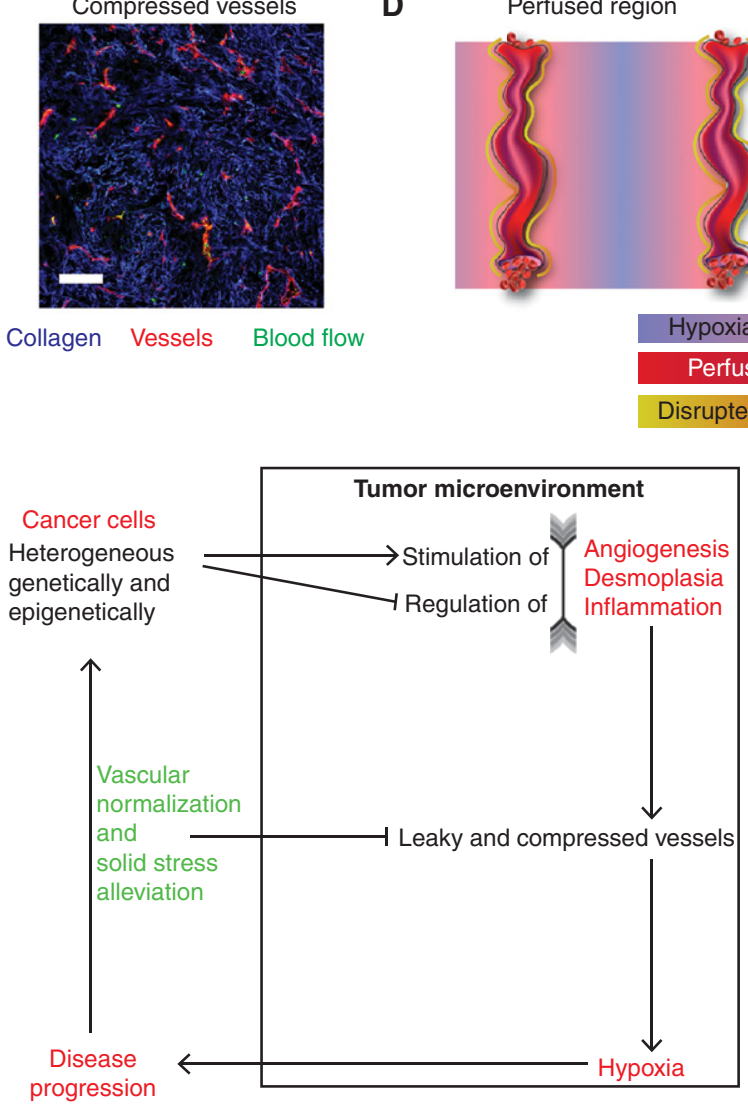

Figure 2. Cancer cells promote angiogenesis, desmoplasia, and inflammation unchecked, which induces a vicious cycle, as the heterogeneous tumor microenvironment (TME), containing leaky and compressed vessels and characterized by hypoxia and acidosis, promotes disease progression. (A) 90-nm liposomes readily extravasate from leaky tumor vessels. Note that the liposomes' extravasation and, thus, the pores at the vessels' walls are heterogeneously distributed. Scale bar, $100 \mu \mathrm{m}$. (Image from Yuan et al. 1994; adapted, with permission, from the authors.) (B) This schematic's left panel depicts a fortified vessel, which is depicted with an intact perivascular layer, supplying a larger volume of tissue with hypoxia (pink) than the immature vessel in the right panel, which is depicted with a disrupted perivascular layer. Arrows depict lengths of efficient oxygen diffusion radially from the vessel. $(C)$ Most vessels (red) in this collagen-rich (blue) tumor lack blood flow (green). Note that few vessels have an open lumen. The compression indicates the presence of elevated solid stress. Scale bar $100 \mu \mathrm{m}$. (Image adapted from data in Chauhan et al. 2012.) (D) This schematic's left panel depicts a perfused tumor region, which has immature tumor vessels closely spaced. The right panel shows a hypoperfused tumor region, as a large volume of tissue lacks a vessel with blood flow. (E) Vascular normalization and solid stress alleviation can break the vicious cycle of abnormal stroma and hypoxia leading to disease progression and treatment resistance. 
Besides collapsing intratumor vessels, solid stress compresses malignant cells (Butcher et al. 2009; Tse et al. 2012) and surrounding normal cells (Fernández-Sánchez et al. 2015), thereby activating aberrant mechanical signaling pathways and invasive phenotypes. Meanwhile, nearby vessels are also compressed, resulting in poor and heterogeneous tissue perfusion and, thus, hypoxia in and around tumors (Hagendoorn et al. 2006). Together, these factors facilitate tumor progression. Solid stress deforms vessels differentially with respect to their intratumoral location, with central vessels being compressed isotropically and peripheral vessels compressed radially yet stretched circumferentially with respect to the tumor (Stylianopoulos et al. 2013). Furthermore, individual vessels are compressed anisotropically. Vessels are buckled radially, which reduces their radius, yet solid stress does not deform vessels axially and, as a result, does not contribute to angiogenesis-induced vessel tortuosity (MacLaurin et al. 2012). In desmoplastic tumors particularly, this buckling results in the collapse of a majority of vessels (Padera et al. 2004; Chauhan et al. 2013; Jacobetz et al. 2013). Consequently, there are hypoperfused tumor regions lacking perfused vessels regardless of the presence of vessels (Fig. 2D). Furthermore, as explained above, compressed lymphatic vessels are nonfunctional leading to elevated IFP (Padera et al. 2002). Even in functional vessels, compression reduces flow, which is inversely proportional to vessel radius to the fourth power (Jain 1988). In summary, vessel compression, in which collagen I and hyaluronan play important roles, results in reduced blood flow and large tumor regions without perfused vessels.

\section{Abnormal Extracellular Matrix}

ECM - produced in excess by CAFs, other stromal cells, and cancer cells-structurally supports the TME and communicates with cancer cells through molecular and mechanical interactions (Lu et al. 2012; Tung et al. 2015). Dense ECM and fibrosis might play a role in tumor initiation, as collagen density in the breast (Boyd et al. 2007) and fibrosis in the liver (El- sharkawy and Mann 2007) and pancreas (Lowenfels et al. 1993) are independent risk factors of cancer in these organs. Besides initiation, the content, organization and biomechanical properties of the ECM contribute to tumor progression. Generally, hyaluronan-rich tumors have a worse prognosis (Ropponen et al. 1998; Ioachim et al. 2002; Auvinen et al. 2013; Whatcott et al. 2015a). Like hyaluronan, collagen has prognostic value. Worse patient outcome is associated with fibrillar collagen alignment in breast cancer (Conklin et al. 2011; Bredfeldt et al. 2014), and elongated collagen fibers in patients with head and neck, colorectal, and esophageal cancers (Hanley et al. 2016). Experimental studies have shown that the organization and stiffening of the collagen fibers by CAFs facilitates cancer cell invasion (Gaggioli et al. 2007; Goetz et al. 2011). Because of the increased accumulation of collagen and other ECM molecules, many tumors are stiffer than normal tissue. For example, the average stiffness of breast cancer lesions (elastic modulus $E \sim$ $4000 \mathrm{~Pa}$ ) is one order of magnitude higher than normal breast $(E \sim 200 \mathrm{~Pa})$ (Samani et al. 2007). In vitro, stiffer matrices of collagen-coated polyacrylamide gels increase chemoresistance (Zustiak et al. 2014). In patients, elastography measurements suggest that stiffness is inversely correlated to response to chemotherapy (Hayashi et al. 2012; Evans et al. 2013). Thus, ECM levels and organization are likely important in tumor initiation, progression, and resistance to therapy.

Besides providing signaling cues for cancer cell invasion and metastasis (Hynes 2009; Goetz et al. 2011; Albrengues et al. 2014), the ECM promotes heterogeneity in the tumor mechanical microenvironment (Jain et al. 2014). The stiff ECM in tumors (Netti et al. 2000; Samani et al. 2007; Giussani et al. 2015) affects cellular behavior (DuFort et al. 2011; Tung et al. 2015) and amplifies solid stress magnitudes by increasing the strain energy stored by force-generating intratumor cells (Stylianopoulos et al. 2012). Hyaluronan and other glycosaminoglycans in the matrix or glycocalyx (Paszek et al. 2014) resist intratumor radial and circumferential compression, which is a result of resistance 
J.D. Martin et al.

to peripheral, circumferential tensile stress by collagen fibers (Chauhan et al. 2013; Stylianopoulos et al. 2013; Pirentis et al. 2015). Thus, the mechanical properties of the ECM contribute to heterogeneous solid stress distribution, thereby dictating the morphology of compressed vessels and oxygen concentrations (Stylianopoulos et al. 2013; Mpekris et al. 2015).

\section{Abnormal Metabolic Microenvironment}

Organs regulate the concentration of oxygen to support their function and survival, yet tumors in general are hypoxic compared with their host tissue because of abnormal vessels. For example, in normal breast tissue, the median partial pressure of oxygen is $65 \mathrm{mmHg}$, but in breast tumors, the median was $<10 \mathrm{mmHg}$, which was less than the lowest measurement in normal breast (Vaupel et al. 2007). Blood vessels efficiently deliver oxygen and other nutrients to cells, which maintain the structure and function in healthy organs, but cancer cells' rapid expansion outgrows the host organ's local blood supply. The inefficient tumor vasculature cannot supply oxygen at a rate to match consumption. As discussed above, the chaotic vasculature leaves certain regions of tumor tissue without functional vessels, whereas other vessels remain poorly functional. Blood flow and hypoxia are not only heterogeneous spatially but also temporally. Thus, there are regions with chronic hypoxia where oxygen cannot diffuse because the regions are too far from the nearest functional vessels, and acute hypoxia where blood flow transiently shuts down leaving the tissue volumes supplied by poorly perfused vessels (Thomlinson and Gray 1955; Brown 1979). Besides temporary stoppage and even reversal of flow, the structural abnormalities of tumor vessels affect the blood supply resulting in reduced oxygen concentrations radially and axially downstream (Jain 1988; Helmlinger et al. 1997). In other words, there are regions of hypoxia even in which there are perfused vessels (Helmlinger et al. 1997). Macroscopically, the periphery is generally well-oxygenated, whereas the necrotic core and peri-necrotic area are hypoxic (Chauhan et al. 2011).
Low extracellular $\mathrm{pH}$ is another hallmark of solid tumors (Engin et al. 1995; Ward and Thompson 2012). Hypoxia is one of several mechanisms causing acidosis in the TME (Chiche et al. 2010), including the production of carbonic acid (Helmlinger et al. 2002). Cancer cells often promote inefficient glycolytic metabolism ("Warburg effect," aerobic glycolysis) rather than oxidative phosphorylation in mitochondria (Vander Heiden et al. 2009). Glycolytic metabolism is an order of magnitude less efficient than oxidative phosphorylation and as a byproduct promotes acidosis, yet it is cancer cells' quickest means of producing energy. Additionally, oxidative phosphorylation requires more oxygen, and hypoxia, through hypoxiainduced signaling, interrupts oxygen consumption by mitochondria. Indeed, tumor metabolism depends on substrate availability (Helmlinger et al. 2002). Besides hypoxia, oncogenic activation and inhibition of tumor-suppressor genes also cause aerobic glycolysis by affecting the expression of metabolic and glycolytic enzymes as well as cell surface nutrient transporters (Chiche et al. 2010). As a result, acidity and hypoxia increase as distance to the nearest vessel also increases (Martin and Jain 1994), yet these radial profiles are not necessarily correlated when considering individual vessels (Helmlinger et al. 1997), which suggests that tumor acidity depends on both genetic and physiological factors. In summary, the stimulation of angiogenesis, desmoplasia, and inflammation impairs the tumor vasculature, which in turn makes the metabolic microenvironment abnormal (Fig. 2E). In the next section, we will summarize the mechanisms through which the abnormal metabolic microenvironment promotes disease progression.

\section{HYPOXIA AND ACIDOSIS PROMOTE TUMOR PROGRESSION}

As summarized above, the interaction between cancer cells, stromal cells, and the ECM leads to vessel leakiness and compression, thereby impairing vascular perfusion and producing an abnormal metabolic microenvironment characterized by focal hypoxia and acidosis. In this 
section, we will summarize the evidence that hypoxia leads to poor outcomes in patients, and the mechanisms by which this microenvironmental heterogeneity induces and stimulates disease progression. We will also highlight how these mechanisms of hypoxia-induced progression also feed back into enhanced angiogenesis, desmoplasia, and inflammation/immunosuppression and the ways in which these three processes are interconnected (Fig. 2E).

\section{Intratumoral Oxygenation as a Prognostic Biomarker}

Patients with more hypoxic tumors generally have a worse outcome (Vaupel and Mayer 2014). The intratumoral measurements of the partial pressure of oxygen using electrodes is a prognostic biomarker in head and neck, soft tissue sarcoma, prostate, and node-negative cervical cancers (Brizel et al. 1996; Adam et al. 1999; Fyles et al. 2002; Movsas et al. 2002; Nordsmark et al. 2005). Electrode measurements are invasive and only possible in certain tumor locations. As a result, histological analysis of hypoxia in excised tissues using endogenous markers and exogenous probes is the most widely used technique. Indeed, several surrogate biomarkers of hypoxia (e.g., hypoxia-inducible factor $1 \alpha$ [HIF- $1 \alpha$ ], HIF- $2 \alpha$, carbonic anhydrase IX) have prognostic significance in several cancer types (Kaanders et al. 2002; Bos et al. 2003; Overgaard et al. 2005; Erler et al. 2006; Koukourakis et al. 2006; Evans et al. 2007; Tan et al. 2009; Yan et al. 2009; Buffa et al. 2010; van Malenstein et al. 2010; Semenza 2014). Unfortunately, these surrogate markers only weakly correlate with electrode measurements of hypoxia (Hutchison et al. 2004; Mayer et al. 2004; Lehmann et al. 2009). Regardless, in most tumor types, hypoxia and surrogate biomarkers of hypoxia can identify patients at higher risk of tumor progression.

\section{Hypoxia-Induced Heterogeneity as a Driver of Tumor Progression}

Intratumor genetic heterogeneity has been recognized as an important driver of cancer evolu- tion and therapy resistance in recent years ( $\mathrm{Ma}$ rusyk et al. 2012; Burrell et al. 2013). Genetic heterogeneity in cancer comprises mutations that inevitably arise during DNA replication in all cells, as well as mutational signatures that reflect specific insults to the genome, such as DNA repair dysfunction or exposure to carcinogens and other microenvironmental factors (Alexandrov et al. 2013). Mutations that arise inevitably may contain insight into the lineage of a tumor (Naxerova et al. 2014). The insults to the genome are factors through which the TME shapes genetic diversity in a tumor (Kaufman et al. 2016). One important such factor is hypoxia, which can reduce the expression of genes governing DNA mismatch repair and homologous recombination pathways (Bindra et al. 2007), leading to genomic instability, particularly in chronically hypoxic microenvironments (Bristow and Hill 2008).

In addition, hypoxia promotes a number of other mechanisms of resistance to cytotoxic therapies, including radio-, chemo-, and immunotherapies (Neri and Supuran 2011; Wilson and Hay 2011; Huang et al. 2012). It is worth noting that hypoxia makes cancer cells more sensitive to some chemotherapies; however, cytotoxic agents hardly reach hypoxic cells in adequate concentration (Wilson and Hay 2011).

Hypoxia-induced signaling mediated by HIF activity plays a role in several steps of the metastatic cascade (Semenza 2012, 2014). To metastasize, cancer cells must migrate within and from the primary tumor, either as single cells or multicellular clusters, a process facilitated by CAFs and myeloid cells (Gaggioli et al. 2007; Joyce and Pollard 2009; Duda et al. 2010). Hypoxia-mediated activation of HIF$1 \alpha$ increases the activity of Snail and Twist, two transcription factors that reduce the expression of E-cadherin and promote epithelial to mesenchymal transition (EMT) (Philip et al. 2013). Interestingly, although EMT-related signaling is not necessarily required for metastasis, it promotes invasion, senescence, a cancer stem cell-like phenotype, and resistance to chemotherapy (Thiery et al. 2009; Fischer et al. 2015; Zheng et al. 2015). Hypoxia induction of HIF$1 \alpha$ also regulates the expression of enzymes 
J.D. Martin et al.

(e.g., lysyl oxidase, procollagen-lysine 2-oxoglutarate 5-dioxygenases 1-3) that polymerize and regulate the alignment of collagen fibers and activity of integrins, thus facilitating cancer cell migration (Erler and Giaccia 2006; Semenza 2014). Finally, the increase in vessel permeability mediated by hypoxia-induced factors, such as angiopoietin-2, VEGF, and angiopoietin-like 4, facilitates the passage of metastatic cancer cells through the blood vessel wall in the lungs (Semenza 2014).

In part, the CSC phenotype, which promotes disease progression by mediating primary tumor growth, is regulated and maintained by HIFs, metastasis, and resistance to therapy (Li et al. 2009; Mohyeldin et al. 2010; Philip et al. 2013; Semenza 2016). CSCs may reside in perivascular or hypoxic niches (Bar 2011; Lee and Simon 2012; Plaks et al. 2015). Some perivascular niches could be hypoxic because the blood carried by tumor vessels can contain hemoglobin with low-oxygen saturation (Helmlinger et al. 1997). Hypoxia can support CSCs, whereas the perivascular location facilitates intravasation leading to metastasis. The perivascular location may also allow activation of the resident/dormant CSCs by ECs through angiocrine factors (Calabrese et al. 2007; Butler et al. 2010) and CSC differentiation into ECs (Wang et al. 2010).

Hypoxia also causes immunosuppression. Under hypoxic conditions, myeloid-derived suppressor cells, macrophages, dendritic cells, and tumor cells express higher levels of immune checkpoint ligands (PD-L1) (Noman et al. 2014), which is one of several mechanisms through which hypoxia inhibits the cytolytic activity of T cells and other immune cell types (Doedens et al. 2010; Motz and Coukos 2013). Additionally, hypoxia can induce macrophages to promote fibrosis (Chen et al. 2014b). Thus, hypoxia interferes with the antitumor effects of immune cells (Noman et al. 2015) and induces these cells to contribute to abnormal vessels and desmoplasia, thereby promoting vessel leakiness and compression. Targeting of hypoxia-induced factors (Chen et al. 2015) or reversing hypoxia through vascular normalization (Huang et al. 2012) could potentiate the anti- tumor effects of both responses. These strategies are discussed below.

Hypoxia promotes the expression of factors that contribute to catabolism of glucose to lactate, producing acidosis. This may be an adaption of cancer cells to intermittent hypoxia (Gatenby and Gillies 2004), or a means of promoting proliferation even at the expense of energy efficiency (Vander Heiden et al. 2009). Endogenous markers of acidosis are potential negative prognostic biomarkers (Giatromanolaki et al. 2001; Koukourakis et al. 2003). Acidosis promotes cancer cell invasion by contributing to the degradation of the ECM (Martinez-Zaguilan et al. 1996; Glunde et al. 2003; Estrella et al. 2013). Acidic microenvironment neutralizes weak-base chemotherapies, thereby promoting resistance to this class of chemotherapeutic agents (Sauvant et al. 2008). Acidosis promotes chromosomal instability thereby making cancer cells more likely to mutate (Morita 1995). Chronic autophagy is a cellular adaptation, which promotes cancer cell survival in acidic TMEs (Wojtkowiak et al. 2012). Immunosuppression is in part caused by acidosis, which inhibits the activity of natural killer cells (Martinez-Zaguilan et al. 1996), the cytolytic activity of $\mathrm{T}$ cells (Fischer et al. 2007), and the polarization of macrophages (El-Kenawi et al. 2015; Riemann et al. 2016). Lactic acid produced by tumor cells also induces the expression of VEGF and polarization of tumor-associated macrophages toward an immunosuppressive phenotype and this effect is mediated by hypoxia-inducible factors (Colegio et al. 2014). Thus, acidosis can also promote angiogenesis, which is caused by and contributes to hypoxia in tumors, and also promotes immunosuppression by converting macrophages into a protumor phenotype, which promotes tumor cell invasion, motility, and intravasation (Noy and Pollard 2014).

\section{STRATEGIES TO ALLEVIATE HYPOXIA AND OVERCOME HETEROGENEITY}

As discussed above, the two primary vessel abnormalities are leakiness and compression. These abnormalities induce focal hypoxia by 
(1) reducing the volume of tissue a single vessel can supply with oxygen and nutrients (Fig. 2B), and (2) increasing the volume of tissue without a perfused vessel nearby (Fig. 2D). Our hypothesis is that alleviating hypoxia by reducing blood vessel abnormalities will inhibit tumor progression, metastasis, immunosuppression, and treatment resistance (Fig. 2E).
Inducing vessel maturation fortifies leaky vessels (Fig. 3A), which may increase the volume of tissue a single vessel can supply with oxygen (Fig. 2B) and recover perfusion of static vessels (Fig. 2D). Decreasing solid stress decompresses vessels (Fig. 3B), thereby reducing the volume of tissue far from a perfused vessel (Fig. 2D). In this section, we will discuss how
A

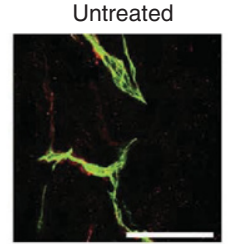

Normalized

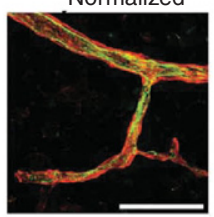

Vessel Pericyte
B

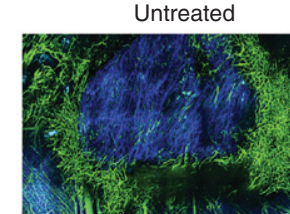

Solid stress alleviated

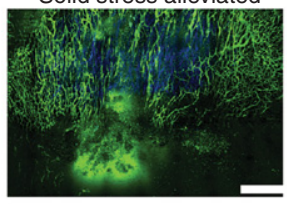

Collagen Perfused vessel
C

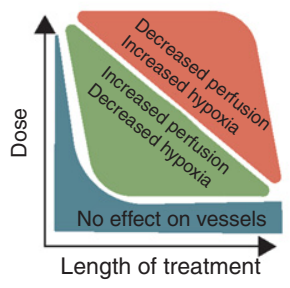

D

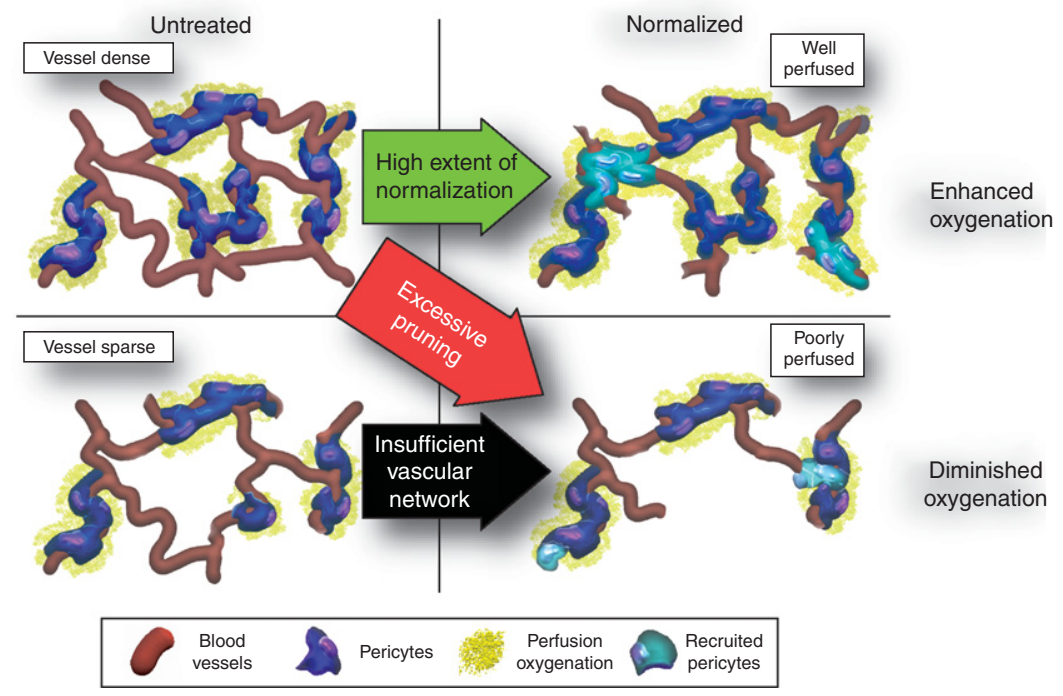

Figure 3. Normalizing vasculature and alleviating solid stress increases tumor perfusion. $(A)$ Vessel normalization involves fortifying vessels (green) with pericytes (red) to make vessels more normal and better functioning. Scale bar, $100 \mu \mathrm{m}$. (From Winkler et al. 2004; reprinted, with permission, from Elsevier (C) 2004.) (B) Solid stress alleviation reperfuses compressed vessels and reduces the volume of tumor regions lacking perfused vessels. Scale bar, $1 \mathrm{~mm}$. (Images from Chauhan et al. 2013.) (C) Vascular normalization by antiangiogenic therapies (AATs) occurs in a time window and increases the effectiveness of anticancer agents because of increased perfusion and oxygenation. High-dose and/or long-treatment periods may result in decreased perfusion. (From Jain 2014; adapted, with permission, from the author.) $(D)$ Vascular normalization by AATs might be more successful if the pretreatment vascular density is high and the normalizing therapy fortifies rather than prunes vessels. (From Tolaney et al. 2015; adapted, with permission, from the authors.) 
J.D. Martin et al.

these strategies are translating from preclinical studies to clinical trials. In addition, we will discuss the exploratory, mechanistic preclinical studies and clinical trials that generate new hypotheses for improving the efficacy and combination of agents that reduce vessel leakiness and compression.

\section{Improving Vascular Function through Vascular Normalization}

In 2001, we proposed that the judicious use of antiangiogenic therapies (AATs) improves the function of intratumoral vessels by pruning immature vessels and fortifying those remaining, thereby promoting more homogenous delivery of oxygen and chemotherapeutic agents (Jain 2001, 2005, 2014; Carmeliet and Jain 2011b). Besides preclinical data (Winkler et al. 2004; Goel et al. 2011), the survival benefit of AATs in patients with colorectal, renal, lung (nonsmall-cell), and other cancers provides evidence supporting the vascular normalization hypothesis (Jain 2014; Vasudev and Reynolds 2014; Jayson et al. 2016). Furthermore, results of hypothesis-generating imaging studies of functional vascular biomarkers in brain, lung, and breast cancer patients support the notion that vascular normalization, and the improved perfusion and oxygenation after AAT are associated with increased survival (Sorensen et al. 2009, 2012; Garcia-Foncillas et al. 2012; Batchelor et al. 2013; Emblem et al. 2013; Heist et al. 2015). Angiogenic and hypoxic gene expression signatures (Franzini et al. 2015) also are consistent with this hypothesis. Thus, AAT has improved patient outcomes in certain settings, with exploratory studies indicating that improved vascular function leading to reduced hypoxia is a potential biomarker of response.

Despite the success of AAT in an adjunct, vascular normalizing role in patients, clinical setbacks in several cancer types-particularly breast and pancreatic cancer-indicate that AATs often fail to improve vessel function (Sledge 2015; Jayson et al. 2016). There are ongoing attempts to validate potential biomarkers (Lambrechts et al. 2013), which are necessary because the normalizing effect of AAT is tran- sient and depends on careful titration of the AAT dose to maximize intratumor oxygen levels (Fig. 3C) (Jain 2014). We hypothesize that the two main factors determining the sensitivity of vascular function and patient outcome to dose and normalization window of AAT are insufficient pretreatment vascular density (Fig. 3D, bottom left quadrant) and excessive vascular pruning (Fig. 3D, top left to bottom right quadrant). Exploratory clinical studies in rectal, colorectal, and breast cancer indicate that better outcome from AATs might be associated with higher pretreatment microvascular density (Fig. 3D, top left quadrant) (Yang et al. 2008; Foernzler et al. 2010; Gasparini et al. 2012; Tolaney et al. 2015). Additionally, related studies in brain and breast cancer indicate that AAT induction of vessel maturation through recruitment of pericytes - and not through pruning of immature vessels-might be associated with improved outcome (Fig. 3D, top left to top right quadrant) (Sorensen et al. 2009; Tolaney et al. 2015). These findings are consistent with data from preclinical studies that show fortification without pruning increases vessel function (Mazzone et al. 2009; Huang et al. 2012). Moreover, there are instances of preclinical and clinical data showing impaired vascular function after pruning despite vessel fortification by AAT (Van der Veldt et al. 2012; Arjaans et al. 2013). These data indicate that AATs, which reduce leakiness without pruning, should be prioritized.

Proangiogenic strategies that stimulate angiogenesis in nonperfused regions, while avoiding pruning and overcoming hypoperfusion, nonetheless will increase vascular leakiness, thereby encountering the opposite problematic dichotomy that pruning AAT poses (Rivera and Bergers 2015; Wong et al. 2015). In contrast, more effective AATs will be more readily combined and tailored to distinct vascular phenotypes, as they fortify vessels - thereby increasing the volume of tissue supplied by single vessels and recover perfusion to static vessels - thereby decreasing the volume of tissue without perfused vessels (Mazzone et al. 2009; Huang et al. 2012; Goel et al. 2013; Maes et al. 2014; Patenaude et al. 2015). As will be discussed be- 
low, solid stress alleviation is a suitable adjunct to vessel-fortifying AATs, as it will increase the density of functional vessels without increasing leakiness (Fig. 4).

Whether the effect is fortification or pruning of immature tumor vessels, AATs are inef- fective in the early metastatic setting (Sledge 2015). Lymph node metastases do not seem to rely on angiogenesis and thus are insensitive to AATs (Jeong et al. 2015). Furthermore, invading cancer cells coopting normal vessels are in normal and normoxic microenvironments, yet they

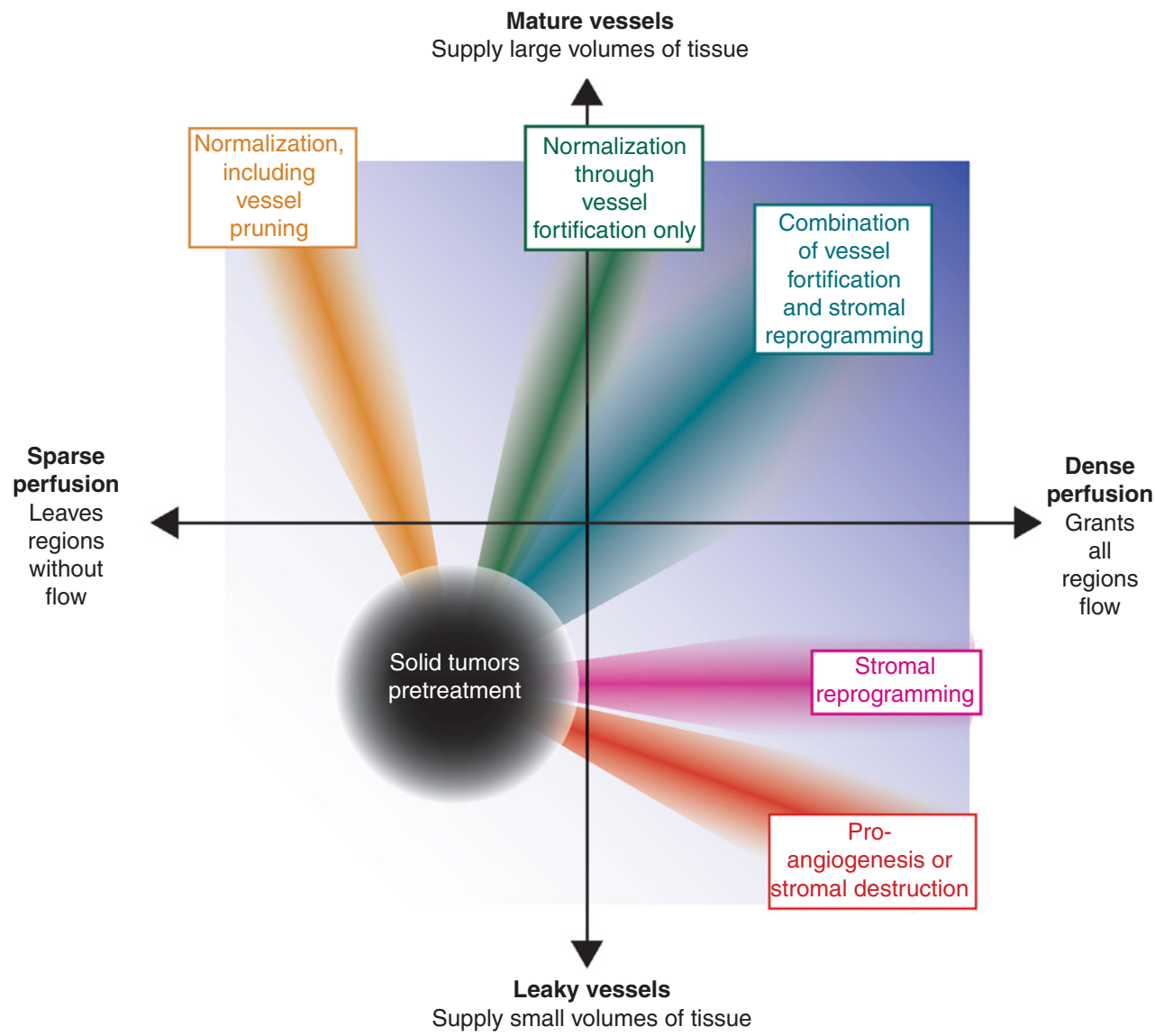

Hypoxia

Normoxia

Figure 4. Combinations of therapies that increase vessel maturity and the density of perfused vessels might be optimal for alleviating hypoxia. Most, but not all, solid tumors have both leaky vessels and regions with sparse perfusion (denoted on graph by black circle) leaving the tissue hypoxic (white background). Reengineering the tumor microenvironment (TME) to eliminate hypoxia and promote normoxia (blue background) could lead to improved treatment outcomes. Normalization strategies that increase vessel maturity often also induce pruning (orange ray), leading to sparse perfusion, whereas proangiogenic and stromal destruction strategies (red ray) increase vessel leakiness. Strategies that normalize vessels through fortification with pericytes while avoiding pruning (green ray) or reprogram the stroma to alleviate solid stress (magenta ray) improve vessel function without detrimental effects, and the combination (greenish blue ray) might be ideal to alleviate hypoxia for most solid tumors. 
J.D. Martin et al.

seem insusceptible to chemotherapies, which is at odds with the notion that vessel function limits the effectiveness of chemotherapy. However, recent findings indicate that metastatic cells particularly are resistant to chemotherapy, because cells cannot invade and proliferate simultaneously (Matus et al. 2015). Similarly, cells under solid stress (Cheng et al. 2009; Desmaison et al. 2013; Delarue et al. 2014) or that have undergone EMT (Fischer et al. 2015; Zheng et al. 2015) proliferate less and are resistant to chemotherapy. Thus, strategies that stimulate proliferation or kill invading cancer cells could be combined with agents that normalize the tumor vasculature in adjuvant and metastatic settings.

\section{Improving Vascular Function by Decompressing Vessels}

The clinical development of therapeutics to decompress vessels is not as advanced as that of AATs. Cancer cells and CAFs generate solid stress, which is stored as strain energy in ECM components like hyaluronan and collagen fibers (Stylianopoulos et al. 2012). In 1999, the first preclinical data were reported showing that pharmacologic vascular decompression leads to reduced hypoxia using the chemotherapy paclitaxel, which kills a fraction of proliferative tumor cells (Griffon-Etienne et al. 1999). Furthermore, paclitaxel, but not chemotherapy of another type, reduces tumor hypoxia in breast cancer patients (Taghian et al. 2005). Perhaps this unique ability to decompress vessels and alleviate hypoxia can be explained not only by cancer cell depletion but also by paclitaxel's ability to reduce CAF and collagen levels (Alvarez et al. 2013). As a result, the addition of Nab-paclitaxel-a nanoparticle formulation of paclitaxel-to gemcitabine improves survival in pancreatic cancer patients, as verified in a randomized, controlled clinical trial (Von Hoff et al. 2013; Whatcott et al. 2015b).

Avoiding the toxicities of chemotherapies, agents that directly target the stroma also reduce solid stress and decompress vessels. Depletion of hyaluronan using pegylated hyaluronidase (PEGPH20) decompresses vessels and improves the outcome of chemotherapy (Provenzano et al. 2012; Jacobetz et al. 2013; Chauhan et al. 2014). Indeed, the combination of PEGPH20 and chemotherapy was effective in a phase II trial of patients with elevated levels of hyaluronan in their lesions (Hingorani et al. 2016). Similarly, hedgehog pathway antagonism, which reduces the activity of CAFs and desmoplasia (Bailey et al. 2008), decreases solid stress and increases perfusion (Stylianopoulos et al. 2012). However, depletion of stroma is a double-edged sword. Genetic depletion of either CAFs (Ozdemir et al. 2014) or pericytes (Cooke et al. 2012) induces hypoxia and promotes disease progression. Similarly, genetic deletion of sonic hedgehog or longterm pharmacological inhibition of its signaling reduces cancer cell differentiation, increases angiogenesis and cancer cell proliferation, and decreases survival (Lee et al. 2014; Rhim et al. 2014). These results provide potential hypotheses for the failure of hedgehog antagonism in clinical trials to increase drug delivery and survival (Catenacci et al. 2015; Whatcott et al. 2015b).

Repurposed pharmacologic agents that reprogram the tumor stroma toward a normal phenotype are promising, because they alleviate hypoxia without destroying stroma (Whatcott et al. 2015b). For example, angiotensin system inhibition (ASI) with losartan inhibits downstream profibrotic pathways-TGF- $\beta 1$, connective tissue growth factor, endothelin1 -in CAFs, and thereby reduces solid stress, decompresses vessels, and increases oxygen and drug delivery without increasing malignancy (Chauhan et al. 2013). There is evidence of ASI-induced vessel decompression in glioblastoma patients (Emblem et al. 2016). Besides decompressing vessels, as TGF- $\beta 1$ promotes protumor immune suppression (Wrzesinski et al. 2007; Pickup et al. 2013; Papageorgis and Stylianopoulos 2015), losartan reduces metastasis by blocking monocyte recruitment (Regan et al. 2016). Supporting these mechanistic data, retrospective clinical analyses suggest that the use of ASI to manage hypertension in cancer patients is correlated with longer survival (Wilop et al. 2009; Nakai et al. 2010, 2015; 
Keizman et al. 2011; Menter et al. 2014), including one analysis of 4736 patients (McKay et al. 2015). Other strategies to reprogram the stroma to decompress vessels include VDR agonism, which induces a quiescent phenotype in PSCs. Like ASI, VDR agonism alleviates desmoplasia, increases vascular function, and potentiates chemotherapy (Sherman et al. 2014; Hah et al. 2015). Similarly, the glucose-lowering drug metformin induces a quiescent phenotype in PSCs and thereby reduces desmoplasia, EMT, and metastasis (Incio et al. 2015), in agreement with retrospective clinical studies (Sadeghi et al. 2012). Because stromal reprogramming improves outcomes in preclinical and retrospective clinical studies by increasing perfusion without increasing vessel leakiness or malignancy, it is readily combinable with vessel-fortifying AATs (Fig. 4) (Stylianopoulos and Jain 2013). Indeed, retrospective studies in renal cell carcinoma and advanced nonsmall-cell lung cancer patients showed survival advantage in patients who received both an AAT (sunitinib and bevacizumab, respectively) and ASI (Keizman et al. 2011; Menter et al. 2014). Randomized, controlled clinical trials must be completed to confirm the survival benefit of stromal reprogramming and its combination with AAT.

\section{CONCLUSION}

Diverse subpopulations of cancer cells together coopt and activate the stroma to create a TME conducive for disease progression. Heterogeneity of the microenvironment in phenotype, function, and topology of stromal constituents results in focal development of tumor hypoxia. Hypoxia fuels a vicious cycle in TME resulting in disease progression through multiple mechanisms. Alleviating hypoxia may delay tumor progression and improve treatment outcomes. With the lack/reduction of focal hypoxia in TME, angiogenesis, desmoplasia, and inflammation would not be promoted, thereby reversing stromal heterogeneity and reducing stromamediated treatment resistance (Junttila and de Sauvage 2013). With respect to cancer cells, regional differences in selective pressures will be reduced, thereby minimizing the rise of mutants, which acquire survival advantage. Additionally, higher concentrations of cytotoxic therapies will reach cancer cells, further reducing the likelihood of resistance. We have proposed two strategies to alleviate hypoxia-vascular normalization and vessel decompression. Combining these two strategies properly could more efficiently alleviate hypoxia, improve the outcome of concurrent radiation, chemo- and immune-therapy, and overcome the challenges posed by tumor heterogeneity (Stylianopoulos and Jain 2013).

\section{ACKNOWLEDGMENTS}

The authors thank Meenal Datta, Dr. Vikash Chauhan, and Dr. Kamila Naxerova for insightful input and Dr. Giorgio Seano for assistance in preparing Figure 2. This research is supported by the National Institutes of Health Grants P01-CA080124 (to R.K.J., Y.B., D.G.D., and D.F.), P50CA165962, R01CA126642, and R35CA197743 (to R.K.J.), R21 CA173518 and R01 CA098706 (to Y.B.), R01-CA096915 and S10-RR027070 (to D.F.), R01-CA159258 (to D.G.D.), and NCI/Federal Share Proton Beam Program Income (to R.K.J. and D.F.); by the Department of Defense (DoD) Breast Cancer Research Innovator Award W81XWH10-1-0016 (to R.K.J.); the Lustgarten Foundation (to R.K.J.); Pancreatic Cancer Action Network-AACR Innovative Grants (to Y.B.); American Cancer Society Research Scholar Award (to D.G.D.); and Warshaw Institute for Pancreatic Cancer Research (to D.G.D. and D.F.). R.K.J. received consultant fees from Ophthotech, SPARC, SynDevRx, and XTuit. R.K.J. owns equity in Enlight, Ophthotech, SynDevRx, and XTuit and serves on the Board of Directors of XTuit and the Boards of Trustees of Tekla Healthcare Investors, Tekla Life Sciences Investors, Tekla Healthcare Opportunities Fund, and Tekla World Healthcare Fund. R.K.J. received grants from MedImmune and Roche; D.G.D. received grants from Merrimack and HealthCare Pharmaceuticals. Y.B. served as consultant for Xtuit. 
J.D. Martin et al.

\section{REFERENCES}

Adam MF, Gabalski EC, Bloch DA, Oehlert JW, Brown JM, Elsaid AA, Pinto HA, Terris DJ. 1999. Tissue oxygen distribution in head and neck cancer patients. Head Neck 21: $146-153$.

Albrengues J, Bourget I, Pons C, Butet V, Hofman P, TartareDeckert S, Feral CC, Meneguzzi G, Gaggioli C. 2014. LIF mediates proinvasive activation of stromal fibroblasts in cancer. Cell Rep 7: 1664-1678.

Albrengues J, Bertero T, Grasset E, Bonan S, Maiel M, Bourget I, Philippe C, Herraiz Serrano C, Benamar S, Croce O, et al. 2015. Epigenetic switch drives the conversion of fibroblasts into proinvasive cancer-associated fibroblasts. Nat Commun 6: 10204.

Alexandrov LB, Nik-Zainal S, Wedge DC, Aparicio SA, Behjati S, Biankin AV, Bignell GR, Bolli N, Borg A, BørresenDale AL. 2013. Signatures of mutational processes in human cancer. Nature 500: 415-421.

Alitalo K. 2011. The lymphatic vasculature in disease. Nat Med 17: 1371-1380.

Alvarez R, Musteanu M, Garcia-Garcia E, Lopez-Casas PP, Megias D, Guerra C, Munoz M, Quijano Y, Cubillo A, Rodriguez-Pascual J, et al. 2013. Stromal disrupting effects of nab-paclitaxel in pancreatic cancer. $\mathrm{Br} J$ Cancer 109: 926-933.

Apte MV, Park S, Phillips PA, Santucci N, Goldstein D, Kumar RK, Ramm GA, Buchler M, Friess H, McCarroll JA, et al. 2004. Desmoplastic reaction in pancreatic cancer: Role of pancreatic stellate cells. Pancreas 29: 179187.

Arjaans M, Oude Munnink TH, Oosting SF, Terwisscha van Scheltinga AG, Gietema JA, Garbacik ET, Timmer-Bosscha H, Lub-de Hooge MN, Schroder CP, de Vries EG. 2013. Bevacizumab-induced normalization of blood vessels in tumors hampers antibody uptake. Cancer Res 73: 3347-3355.

Auvinen P, Tammi R, Kosma VM, Sironen R, Soini Y, Mannermaa A, Tumelius R, Uljas E, Tammi M. 2013. Increased hyaluronan content and stromal cell CD44 associate with HER2 positivity and poor prognosis in human breast cancer. Int J Cancer 132: 531-539.

Bailey JM, Swanson BJ, Hamada T, Eggers JP, Singh PK, Caffery T, Ouellette MM, Hollingsworth MA. 2008. Sonic hedgehog promotes desmoplasia in pancreatic cancer. Clin Cancer Res 14: 5995-6004.

Baish JW, Netti PA, Jain RK. 1997. Transmural coupling of fluid flow in microcirculatory network and interstitium in tumors. Microvasc Res 53: 128-141.

Baish JW, Stylianopoulos T, Lanning RM, Kamoun WS, Fukumura D, Munn LL, Jain RK. 2011. Scaling rules for diffusive drug delivery in tumor and normal tissues. Proc Natl Acad Sci 108: 1799-1803.

Bar EE. 2011. Glioblastoma, cancer stem cells and hypoxia. Brain Pathol 21: 119-129.

Batchelor TT, Gerstner ER, Emblem KE, Duda DG, Kalpathy-Cramer J, Snuderl M, Ancukiewicz M, Polaskova P, Pinho MC, Jennings D, et al. 2013. Improved tumor oxygenation and survival in glioblastoma patients who show increased blood perfusion after cediranib and chemoradiation. Proc Natl Acad Sci 110: 19059-19064.
Beatty GL, Chiorean EG, Fishman MP, Saboury B, Teitelbaum UR, Sun W, Huhn RD, Song W, Li D, Sharp LL. 2011. CD40 agonists alter tumor stroma and show efficacy against pancreatic carcinoma in mice and humans. Science 331: 1612-1616.

Bedard PL, Hansen AR, Ratain MJ, Siu LL. 2013. Tumour heterogeneity in the clinic. Nature 501: 355-364.

Bindra RS, Crosby ME, Glazer PM. 2007. Regulation of DNA repair in hypoxic cancer cells. Cancer Metastasis Rev 26: 249-260.

Bos R, van der Groep P, Greijer AE, Shvarts A, Meijer S, Pinedo HM, Semenza GL, van Diest PJ, van der Wall E. 2003. Levels of hypoxia-inducible factor- $1 \alpha$ independently predict prognosis in patients with lymph node negative breast carcinoma. Cancer 97: 1573-1581.

Boucher Y, Jain RK. 1992. Microvascular pressure is the principal driving force for interstitial hypertension in solid tumors: Implications for vascular collapse. Cancer Res 52: 5110-5114.

Boucher Y, Baxter LT, Jain RK. 1990. Interstitial pressure gradients in tissue-isolated and subcutaneous tumors: Implications for therapy. Cancer Res 50: 4478-4484.

Boyd NF, Guo H, Martin LJ, Sun L, Stone J, Fishell E, Jong RA, Hislop G, Chiarelli A, Minkin S. 2007. Mammographic density and the risk and detection of breast cancer. N Engl J Med 356: 227-236.

Bredfeldt JS, Liu Y, Conklin MW, Keely PJ, Mackie TR, Eliceiri KW. 2014. Automated quantification of aligned collagen for human breast carcinoma prognosis. J Pathol Inform 5: 28.

Bristow RG, Hill RP. 2008. Hypoxia and metabolism. Hypoxia, DNA repair and genetic instability. Nat Rev Cancer 8: $180-192$.

Brizel DM, Scully SP, Harrelson JM, Layfield LJ, Bean JM, Prosnitz LR, Dewhirst MW. 1996. Tumor oxygenation predicts for the likelihood of distant metastases in human soft tissue sarcoma. Cancer Res 56: 941-943.

Brown JM. 1979. Evidence for acutely hypoxic cells in mouse tumours, and a possible mechanism of reoxygenation. $\mathrm{Br}$ J Radiol 52: 650-656.

Buffa FM, Harris AL, West CM, Miller CJ. 2010. Large metaanalysis of multiple cancers reveals a common, compact and highly prognostic hypoxia metagene. $\mathrm{Br} J$ Cancer 102: $428-435$.

Burrell RA, McGranahan N, Bartek J, Swanton C. 2013. The causes and consequences of genetic heterogeneity in cancer evolution. Nature 501: 338-345.

Butcher DT, Alliston T, Weaver VM. 2009. A tense situation: Forcing tumour progression. Nat Rev Cancer 9: 108-122.

Butler JM, Kobayashi H, Rafii S. 2010. Instructive role of the vascular niche in promoting tumour growth and tissue repair by angiocrine factors. Nat Rev Cancer 10: 138-146.

Calabrese C, Poppleton H, Kocak M, Hogg TL, Fuller C, Hamner B, Oh EY, Gaber MW, Finklestein D, Allen M, et al. 2007. A perivascular niche for brain tumor stem cells. Cancer Cell 11: 69-82.

Carmeliet P, Jain RK. 2011a. Molecular mechanisms and clinical applications of angiogenesis. Nature 473: $298-$ 307. 
Carmeliet P, Jain RK. 2011b. Principles and mechanisms of vessel normalization for cancer and other angiogenic diseases. Nat Rev Drug Discov 10: 417-427.

Catenacci DV, Junttila MR, Karrison T, Bahary N, Horiba MN, Nattam SR, Marsh R, Wallace J, Kozloff M, Rajdev L, et al. 2015. Randomized phase Ib/II study of gemcitabine plus placebo or Vismodegib, a Hedgehog pathway inhibitor, in patients with metastatic pancreatic cancer. J Clin Oncol 33: 4284-4292.

Chanmee T, Ontong P, Mochizuki N, Kongtawelert P, Konno K, Itano N. 2014. Excessive hyaluronan production promotes acquisition of cancer stem cell signatures through the coordinated regulation of twist and the transforming growth factor $\beta$ (TGF- $\beta$ )-snail signaling axis. J Biol Chem 289: $26038-26056$.

Chauhan VP, Stylianopoulos T, Boucher Y, Jain RK. 2011. Delivery of molecular and nanoscale medicine to tumors: Transport barriers and strategies. Annu Rev Chem Biomol Eng 2: 281-298.

Chauhan VP, Stylianopoulos T, Martin JD, Popovic Z, Chen O, Kamoun WS, Bawendi MG, Fukumura D, Jain RK. 2012. Normalization of tumour blood vessels improves the delivery of nanomedicines in a size-dependent manner. Nat Nanotechnol 7: 383-388.

Chauhan VP, Martin JD, Liu H, Lacorre DA, Jain SR, Kozin SV, Stylianopoulos T, Mousa AS, Han X, Adstamongkonkul P, et al. 2013. Angiotensin inhibition enhances drug delivery and potentiates chemotherapy by decompressing tumour blood vessels. Nat Commun 4: 2516.

Chauhan VP, Boucher Y, Ferrone CR, Roberge S, Martin JD, Stylianopoulos T, Bardeesy N, DePinho RA, Padera TP, Munn LL. 2014. Compression of pancreatic tumor blood vessels by hyaluronan is caused by solid stress and not interstitial fluid pressure. Cancer Cell 26: 14-15.

Chen WJ, Ho CC, Chang YL, Chen HY, Lin CA, Ling TY, Yu SL, Yuan SS, Chen YJ, Lin CY, et al. 2014a. Cancer-associated fibroblasts regulate the plasticity of lung cancer stemness via paracrine signalling. Nat Commun 5: 3472.

Chen Y, Huang Y, Reiberger T, Duyverman AM, Huang P, Samuel R, Hiddingh L, Roberge S, Koppel C, Lauwers GY, et al. 2014b. Differential effects of sorafenib on liver versus tumor fibrosis mediated by stromal-derived factor $1 \alpha / \mathrm{C}-\mathrm{X}-\mathrm{C}$ receptor type 4 axis and myeloid differentiation antigen-positive myeloid cell infiltration in mice. Hepatology 59: 1435-1447.

Chen Y, Ramjiawan RR, Reiberger T, Ng MR, Hato T, Huang Y, Ochiai H, Kitahara S, Unan EC, Reddy TP, et al. 2015. CXCR4 inhibition in tumor microenvironment facilitates anti-programmed death receptor-1 immunotherapy in sorafenib-treated hepatocellular carcinoma in mice. Hepatology 61: 1591-1602.

Cheng G, Tse J, Jain RK, Munn LL. 2009. Micro-environmental mechanical stress controls tumor spheroid size and morphology by suppressing proliferation and inducing apoptosis in cancer cells. PLoS ONE 4: e4632.

Chiche J, Brahimi-Horn MC, Pouyssegur J. 2010. Tumour hypoxia induces a metabolic shift causing acidosis: A common feature in cancer. J Cell Mol Med 14: 771-794.

Colegio OR, Chu NQ, Szabo AL, Chu T, Rhebergen AM, Jairam V, Cyrus N, Brokowski CE, Eisenbarth SC, Phillips GM, et al. 2014. Functional polarization of tumour-as-
Reengineering the Tumor Microenvironment

sociated macrophages by tumour-derived lactic acid. $\mathrm{Na}$ ture 513: 559-563.

Conklin MW, Eickhoff JC, Riching KM, Pehlke CA, Eliceiri KW, Provenzano PP, Friedl A, Keely PJ. 2011. Aligned collagen is a prognostic signature for survival in human breast carcinoma. Am J Pathol 178: 1221-1232.

Cooke VG, LeBleu VS, Keskin D, Khan Z, O'Connell JT, Teng Y, Duncan MB, Xie L, Maeda G, Vong S, et al. 2012. Pericyte depletion results in hypoxia-associated epithelial-to-mesenchymal transition and metastasis mediated by met signaling pathway. Cancer Cell 21: 66-81.

Coussens LM, Zitvogel L, Palucka AK. 2013. Neutralizing tumor-promoting chronic inflammation: A magic bullet? Science 339: 286-291.

Croix BS, Rago C, Velculescu V, Traverso G, Romans KE, Montgomery E, Lal A, Riggins GJ, Lengauer C, Vogelstein B. 2000. Genes expressed in human tumor endothelium. Science 289: 1197-1202.

Delarue M, Montel F, Vignjevic D, Prost J, Joanny JF, Cappello G. 2014. Compressive stress inhibits proliferation in tumor spheroids through a volume limitation. Biophys $J$ 107: $1821-1828$.

DeNardo DG, Barreto JB, Andreu P, Vasquez L, Tawfik D, Kolhatkar N, Coussens LM. 2009. CD4 ${ }^{+}$T cells regulate pulmonary metastasis of mammary carcinomas by enhancing protumor properties of macrophages. Cancer Cell 16: 91-102.

DeNardo DG, Andreu P, Coussens LM. 2010. Interactions between lymphocytes and myeloid cells regulate proversus anti-tumor immunity. Cancer Metastasis Rev 29: 309-316.

DeNardo DG, Brennan DJ, Rexhepaj E, Ruffell B, Shiao SL, Madden SF, Gallagher WM, Wadhwani N, Keil SD, Junaid SA, et al. 2011. Leukocyte complexity predicts breast cancer survival and functionally regulates response to chemotherapy. Cancer Discov 1: 54-67.

Desmaison A, Frongia C, Grenier K, Ducommun B, Lobjois V. 2013. Mechanical stress impairs mitosis progression in multi-cellular tumor spheroids. PLoS ONE 8: e80447.

Ding N, Yu RT, Subramaniam N, Sherman MH, Wilson C, Rao R, Leblanc M, Coulter S, He M, Scott C, et al. 2013. A vitamin $\mathrm{D}$ receptor/SMAD genomic circuit gates hepatic fibrotic response. Cell 153: 601-613.

Doedens AL, Stockmann C, Rubinstein MP, Liao D, Zhang N, DeNardo DG, Coussens LM, Karin M, Goldrath AW, Johnson RS. 2010. Macrophage expression of hypoxiainducible factor- $1 \alpha$ suppresses T-cell function and promotes tumor progression. Cancer Res 70: 7465-7475.

Duda DG, Duyverman AM, Kohno M, Snuderl M, Steller EJ, Fukumura D, Jain RK. 2010. Malignant cells facilitate lung metastasis by bringing their own soil. Proc Natl Acad Sci 107: 21677-21682.

DuFort CC, Paszek MJ, Weaver VM. 2011. Balancing forces: Architectural control of mechanotransduction. Nat Rev Mol Cell Biol 12: 308-319.

El-Kenawi AE, Ibrahim-Hashim AA, Luddy KA, PilonThomas SA, Gatenby RA, Gillies RJ. 2015. Extracellular acidosis alters polarization of macrophages. Cancer Res 75: 3213-3213. 
J.D. Martin et al.

Elsharkawy AM, Mann DA. 2007. Nuclear factor-кB and the hepatic inflammation-fibrosis-cancer axis. Hepatology 46: 590-597.

Emblem KE, Mouridsen K, Bjornerud A, Farrar CT, Jennings D, Borra RJ, Wen PY, Ivy P, Batchelor TT, Rosen BR, et al. 2013. Vessel architectural imaging identifies cancer patient responders to anti-angiogenic therapy. Nat Med 19: 1178-1183.

Emblem KE, Gerstner ER, Sorensen AG, Wen PY, Batchelor TT, Jain RK. 2016. Matrix-depleting anti-hypertensives decompress tumor blood vessels and improve perfusion in patients with glioblastomas receiving anti-angiogenic therapy. AACR Annual Meeting 2016, Abstract 3975. New Orleans, LA, April 16-20.

Engin K, Leeper DB, Cater JR, Thistlethwaite AJ, Tupchong L, McFarlane JD. 1995. Extracellular pH distribution in human tumours. Int J Hyperthermia 11: 211-216.

Erez N, Truitt M, Olson P, Arron ST, Hanahan D. 2010. Cancer-associated fibroblasts are activated in incipient neoplasia to orchestrate tumor-promoting inflammation in an NF-кB-dependent manner. Cancer Cell 17: 135147.

Erler JT, Giaccia AJ. 2006. Lysyl oxidase mediates hypoxic control of metastasis. Cancer Res 66: 10238-10241.

Erler JT, Bennewith KL, Nicolau M, Dornhöfer N, Kong C, Le QT, Chi JTA, Jeffrey SS, Giaccia AJ. 2006. Lysyl oxidase is essential for hypoxia-induced metastasis. Nature 440: $1222-1226$.

Estrella V, Chen T, Lloyd M, Wojtkowiak J, Cornnell HH, Ibrahim-Hashim A, Bailey K, Balagurunathan Y, Rothberg JM, Sloane BF, et al. 2013. Acidity generated by the tumor microenvironment drives local invasion. Cancer Res 73: 1524-1535.

Evans SM, Du KL, Chalian AA, Mick R, Zhang PJ, Hahn SM, Quon H, Lustig R, Weinstein GS, Koch CJ. 2007. Patterns and levels of hypoxia in head and neck squamous cell carcinomas and their relationship to patient outcome. Int J Radiat Oncol Biol Phys 69: 1024-1031.

Evans A, Armstrong S, Whelehan P, Thomson K, Rauchhaus P, Purdie C, Jordan L, Jones L, Thompson A, Vinnicombe S. 2013. Can shear-wave elastography predict response to neoadjuvant chemotherapy in women with invasive breast cancer? Br J Cancer 109: 2798-2802.

Facciabene A, Peng X, Hagemann IS, Balint K, Barchetti A, Wang LP, Gimotty PA, Gilks CB, Lal P, Zhang L. 2011. Tumour hypoxia promotes tolerance and angiogenesis via CCL28 and Treg cells. Nature 475: 226-230.

Fernández-Sánchez ME, Barbier S, Whitehead J, Béalle G, Michel A, Latorre-Ossa H, Rey C, Fouassier L, Claperon A, Brullé L. 2015. Mechanical induction of the tumorigenic $\beta$-catenin pathway by tumour growth pressure. Nature 523: 92-95.

Fischer K, Hoffmann P, Voelkl S, Meidenbauer N, Ammer J, Edinger M, Gottfried E, Schwarz S, Rothe G, Hoves S, et al. 2007. Inhibitory effect of tumor cell-derived lactic acid on human T cells. Blood 109: 3812-3819.

Fischer KR, Durrans A, Lee S, Sheng J, Li F, Wong ST, Choi H, El Rayes T, Ryu S, Troeger J. 2015. Epithelial-to-mesenchymal transition is not required for lung metastasis but contributes to chemoresistance. Nature 527: $472-$ 476.
Foernzler D, Delmar P, Kockx M, Cassidy J, Saltz L, Scherer S. 2010. Tumor tissue based biomarker analysis in NO16966: A randomized phase III study of first-line bevacizumab in combination with oxaliplatin-based chemotherapy in patients with mCRC. 2010 GastroIntestinal Cancers Symposium, Abstract 374. Orlando, FL, January $22-24$.

Franzini A, Baty F, Macovei II, Durr O, Droege C, Betticher D, Grigoriu BD, Klingbiel D, Zappa F, Brutsche M. 2015. Gene expression signatures predictive of bevacizumab/ erlotinib therapeutic benefit in advanced non-squamous non-small cell lung cancer patients (SAKK 19/05 trial). Clin Cancer Res 21: 5253-5263.

Fukumura D, Xavier R, Sugiura T, Chen Y, Park EC, Lu N, Selig M, Nielsen G, Taksir T, Jain RK, et al. 1998. Tumor induction of VEGF promoter activity in stromal cells. Cell 94: 715-725.

Fyles A, Milosevic M, Hedley D, Pintilie M, Levin W, Manchul L, Hill R. 2002. Tumor hypoxia has independent predictor impact only in patients with node-negative cervix cancer. J Clin Oncol 20: 680-687.

Gaggioli C, Hooper S, Hidalgo-Carcedo C, Grosse R, Marshall JF, Harrington K, Sahai E. 2007. Fibroblast-led collective invasion of carcinoma cells with differing roles for RhoGTPases in leading and following cells. Nat Cell Biol 9: $1392-1400$.

Garcia-Foncillas J, Martinez P, Lahuerta A, Cussac AL, Gonzalez MG, Sanchez Gomez RM, Alvarez I, Anton A, Illarramendi JJ, De Juan A, et al. 2012. Dynamic contrast-enhanced MRI versus 18F-misonidazol-PET/CT to predict pathologic response in bevacizumab-based neoadjuvant therapy in breast cancer. J Clin Oncol 30 (suppl; abstr 10512).

Gasparini G, Torino F, Ueno T, Cascinu S, Troiani T, Ballestrero A, Berardi R, Shishido J, Yoshizawa A, Mori Y, et al. 2012. A phase II study of neoadjuvant bevacizumab plus capecitabine and concomitant radiotherapy in patients with locally advanced rectal cancer. Angiogenesis 15: 141 150.

Gatenby RA, Gillies RJ. 2004. Why do cancers have high aerobic glycolysis? Nat Rev Cancer 4: 891-899.

Gerhardt H, Golding M, Fruttiger M, Ruhrberg C, Lundkvist A, Abramsson A, Jeltsch M, Mitchell C, Alitalo K, Shima D, et al. 2003. VEGF guides angiogenic sprouting utilizing endothelial tip cell filopodia. J Cell Biol 161: 1163-1177.

Giatromanolaki A, Koukourakis MI, Sivridis E, Pastorek J, Wykoff CC, Gatter KC, Harris AL. 2001. Expression of hypoxia-inducible carbonic anhydrase-9 relates to angiogenic pathways and independently to poor outcome in non-small cell lung cancer. Cancer Res 61: 7992-7998.

Giussani M, Merlino G, Cappelletti V, Tagliabue E, Daidone MG. 2015. Tumor-extracellular matrix interactions: Identification of tools associated with breast cancer progression. Semin Cancer Biol 35: 3-10.

Glunde K, Guggino SE, Solaiyappan M, Pathak AP, Ichikawa Y, Bhujwalla ZM. 2003. Extracellular acidification alters lysosomal trafficking in human breast cancer cells. Neoplasia 5: 533-545.

Goel S, Duda DG, Xu L, Munn LL, Boucher Y, Fukumura D, Jain RK. 2011. Normalization of the vasculature for treat- 
ment of cancer and other diseases. Physiol Rev 91: 10711121.

Goel S, Gupta N, Walcott BP, Snuderl M, Kesler CT, Kirkpatrick ND, Heishi T, Huang Y, Martin JD, Ager E, et al. 2013. Effects of vascular-endothelial protein tyrosine phosphatase inhibition on breast cancer vasculature and metastatic progression. J Natl Cancer Inst 105: $1188-1201$.

Goetz JG, Minguet S, Navarro-Lerida I, Lazcano JJ, Samaniego R, Calvo E, Tello M, Osteso-Ibanez T, Pellinen T, Echarri A, et al. 2011. Biomechanical remodeling of the microenvironment by stromal caveolin-1 favors tumor invasion and metastasis. Cell 146: 148-163.

Griffon-Etienne G, Boucher Y, Brekken C, Suit HD, Jain RK. 1999. Taxane-induced apoptosis decompresses blood vessels and lowers interstitial fluid pressure in solid tumors: Clinical implications. Cancer Res 59: 3776-3782.

Hagendoorn J, Tong R, Fukumura D, Lin Q, Lobo J, Padera TP, Xu L, Kucherlapati R, Jain RK. 2006. Onset of abnormal blood and lymphatic vessel function and interstitial hypertension in early stages of carcinogenesis. Cancer Res 66: $3360-3364$.

Hah N, Sherman MH, Yu RT, Downes M, Evans RM. 2015. Targeting transcriptional and epigenetic reprogramming in stromal cells in fibrosis and cancer. Cold Spring Harb Symp Quant Biol 80: 249-255.

Hanley CJ, Noble F, Ward M, Bullock M, Drifka C, Mellone M, Manousopoulou A, Johnston HE, Hayden A, Thirdborough S, et al. 2016. A subset of myofibroblastic cancer-associated fibroblasts regulate collagen fiber elongation, which is prognostic in multiple cancers. Oncotarget 7: 6159-6174.

Haqq J, Howells LM, Garcea G, Metcalfe MS, Steward WP, Dennison AR. 2014. Pancreatic stellate cells and pancreas cancer: Current perspectives and future strategies. Eur J Cancer 50: 2570-2582.

Hashizume H, Baluk P, Morikawa S, McLean JW, Thurston G, Roberge S, Jain RK, McDonald DM. 2000. Openings between defective endothelial cells explain tumor vessel leakiness. Am J Pathol 156: 1363-1380.

Hayashi M, Yamamoto Y, Ibusuki M, Fujiwara S, Yamamoto S, Tomita S, Nakano M, Murakami K, Iyama K, Iwase H 2012. Evaluation of tumor stiffness by elastography is predictive for pathologic complete response to neoadjuvant chemotherapy in patients with breast cancer. Ann Surg Oncol 19: 3042-3049.

Heist RS, Duda DG, Sahani DV, Ancukiewicz M, Fidias P, Sequist LV, Temel JS, Shaw AT, Pennell NA, Neal JW, et al. 2015. Improved tumor vascularization after anti-VEGF therapy with carboplatin and nab-paclitaxel associates with survival in lung cancer. Proc Natl Acad Sci 112: 1547-1552.

Helmlinger G, Yuan F, Dellian M, Jain RK. 1997. Interstitial $\mathrm{pH}$ and $\mathrm{pO}_{2}$ gradients in solid tumors in vivo: Highresolution measurements reveal a lack of correlation. Nat Med 3: 177-182.

Helmlinger G, Sckell A, Dellian M, Forbes NS, Jain RK. 2002. Acid production in glycolysis-impaired tumors provides new insights into tumor metabolism. Clin Cancer Res 8: 1284-1291.

Hida K, Hida Y, Amin DN, Flint AF, Panigrahy D, Morton CC, Klagsbrun M. 2004. Tumor-associated endothelial
Reengineering the Tumor Microenvironment

cells with cytogenetic abnormalities. Cancer Res 64: 8249-8255.

Hingorani SR, Harris WP, Beck JT, Berdov BA, Wagner SA, Pshevlotsky EM, Tjulandin SA, Gladkov OA, Holcombe RF, Korn R, et al. 2016. Phase Ib study of PEGylated recombinant human hyaluronidase and gemcitabine in patients with advanced pancreatic cancer. Clin Cancer Res 22: $2848-2854$.

Hobbs SK, Monsky WL, Yuan F, Roberts WG, Griffith L, Torchilin VP, Jain RK. 1998. Regulation of transport pathways in tumor vessels: Role of tumor type and microenvironment. Proc Natl Acad Sci 95: 4607-4612.

Huang Y, Yuan J, Righi E, Kamoun WS, Ancukiewicz M, Nezivar J, Santosuosso M, Martin JD, Martin MR, Vianello F, et al. 2012. Vascular normalizing doses of antiangiogenic treatment reprogram the immunosuppressive tumor microenvironment and enhance immunotherapy. Proc Natl Acad Sci 109: 17561-17566.

Hutchison GJ, Valentine HR, Loncaster JA, Davidson SE, Hunter RD, Roberts SA, Harris AL, Stratford IJ, Price PM, West CM. 2004. Hypoxia-inducible factor $1 \alpha$ expression as an intrinsic marker of hypoxia correlation with tumor oxygen, pimonidazole measurements, and outcome in locally advanced carcinoma of the cervix. Clin Cancer Res 10: 8405-8412.

Hynes RO. 2009. The extracellular matrix: Not just pretty fibrils. Science 326: 1216-1219.

Incio J, Suboj P, Chin SM, Vardam-Kaur T, Liu H, Hato T, Babykutty S, Chen I, Deshpande V, Jain RK, et al. 2015. Metformin reduces desmoplasia in pancreatic cancer by reprogramming stellate cells and tumor-associated macrophages. PLoS ONE 10: e0141392.

Incio J, Tam J, Rahbari NN, Suboj P, McManus DT, Chin SM, Vardam T, Batista A, Babykutty S, Jung K, et al. 2016a. PlGF/VEGFR-1 signaling promotes macrophage polarization and accelerated tumor progression in obesity. Clin Cancer Res 22: 2993-3004.

Incio J, Liu H, Suboj P, Chin SM, Chen IX, Pinter M, Ng MR, Nia HT, Grahovac J, Kao S, et al. 2016b. Obesity-induced inflammation and desmoplasia promote pancreatic cancer progression and resistance to chemotherapy. Cancer Discov doi: 10.1158/2159-8290.

Ioachim E, Charchanti A, Briasoulis E, Karavasilis V, Tsanou H, Arvanitis D, Agnantis N, Pavlidis N. 2002. Immunohistochemical expression of extracellular matrix components tenascin, fibronectin, collagen type IV and laminin in breast cancer: Their prognostic value and role in tumour invasion and progression. Eur J Cancer 38: 23622370.

Ishii G, Ochiai A, Neri S. 2015. Phenotypic and functional heterogeneity of cancer-associated fibroblast within the tumor microenvironment. Adv Drug Deliv Rev 99: 186-196.

Jacobetz MA, Chan DS, Neesse A, Bapiro TE, Cook N, Frese KK, Feig C, Nakagawa T, Caldwell ME, Zecchini HI, et al. 2013. Hyaluronan impairs vascular function and drug delivery in a mouse model of pancreatic cancer. Gut 62: 112-120.

Jain RK. 1988. Determinants of tumor blood flow: A review. Cancer Res 48: 2641-2658. 
J.D. Martin et al.

Jain RK. 2001. Normalizing tumor vasculature with antiangiogenic therapy: A new paradigm for combination therapy. Nat Med 7: 987-989.

Jain RK. 2003. Molecular regulation of vessel maturation. Nat Med 9: 685-693.

Jain RK. 2005. Normalization of tumor vasculature: An emerging concept in antiangiogenic therapy. Science 307: $58-62$.

Jain RK. 2014. Antiangiogenesis strategies revisited: From starving tumors to alleviating hypoxia. Cancer Cell 26: 605-622.

Jain RK, Tong RT, Munn LL. 2007. Effect of vascular normalization by antiangiogenic therapy on interstitial hypertension, peritumor edema, and lymphatic metastasis: Insights from a mathematical model. Cancer Res 67: 2729-2735.

Jain RK, Martin JD, Stylianopoulos T. 2014. The role of mechanical forces in tumor growth and therapy. Annu Rev Biomed Eng 16: 321-346.

Jayson GC, Kerbel R, Ellis LM, Harris AL. 2016. Antiangiogenic therapy in oncology: Current status and future directions. Lancet 388: 518-529.

Jeong HS, Jones D, Liao S, Wattson DA, Cui CH, Duda DG, Willett CG, Jain RK, Padera TP. 2015. Investigation of the lack of angiogenesis in the formation of lymph node metastases. J Natl Cancer Inst 107: djv155.

Joyce JA, Pollard JW. 2009. Microenvironmental regulation of metastasis. Nat Rev Cancer 9: 239-252.

Junttila MR, de Sauvage FJ. 2013. Influence of tumour micro-environment heterogeneity on therapeutic response. Nature 501: 346-354.

Kaanders JH, Wijffels KI, Marres HA, Ljungkvist AS, Pop LA, van den Hoogen FJ, de Wilde PC, Bussink J, Raleigh JA, van der Kogel AJ. 2002. Pimonidazole binding and tumor vascularity predict for treatment outcome in head and neck cancer. Cancer Res 62: 7066-7074.

Kaufman CK, Mosimann C, Fan ZP, Yang S, Thomas AJ, Ablain J, Tan JL, Fogley RD, van Rooijen E, Hagedorn EJ, et al. 2016. A zebrafish melanoma model reveals emergence of neural crest identity during melanoma initiation. Science 351: aad2197.

Keizman D, Huang P, Eisenberger MA, Pili R, Kim JJ, Antonarakis ES, Hammers H, Carducci MA. 2011. Angiotensin system inhibitors and outcome of sunitinib treatment in patients with metastatic renal cell carcinoma: A retrospective examination. Eur J Cancer 47: 1955-1961.

Kesler CT, Liao S, Munn LL, Padera TP. 2013. Lymphatic vessels in health and disease. Wiley Interdiscip Rev Syst Biol Med 5: 111-124.

Koukourakis M, Giatromanolaki A, Sivridis E, Bougioukas G, Didilis V, Gatter K, Harris A. 2003. Lactate dehydrogenase-5 (LDH-5) overexpression in non-small-cell lung cancer tissues is linked to tumour hypoxia, angiogenic factor production and poor prognosis. Br J Cancer 89: $877-885$.

Koukourakis MI, Bentzen SM, Giatromanolaki A, Wilson GD, Daley FM, Saunders MI, Dische S, Sivridis E, Harris AL. 2006. Endogenous markers of two separate hypoxia response pathways (hypoxia inducible factor $2 \alpha$ and carbonic anhydrase 9) are associated with radiotherapy failure in head and neck cancer patients recruited in the CHART randomized trial. J Clin Oncol 24: 727-735.

Kraman M, Bambrough PJ, Arnold JN, Roberts EW, Magiera L, Jones JO, Gopinathan A, Tuveson DA, Fearon DT. 2010. Suppression of antitumor immunity by stromal cells expressing fibroblast activation protein- $\alpha$. Science 330: $827-830$.

Lambrechts D, Lenz HJ, de Haas S, Carmeliet P, Scherer SJ. 2013. Markers of response for the antiangiogenic agent bevacizumab. J Clin Oncol 31: 1219-1230.

Lee KE, Simon MC. 2012. From stem cells to cancer stem cells: HIF takes the stage. Curr Opin Cell Biol 24: 232235.

Lee JJ, Perera RM, Wang H, Wu DC, Liu XS, Han S, Fitamant J, Jones PD, Ghanta KS, Kawano S, et al. 2014. Stromal response to Hedgehog signaling restrains pancreatic cancer progression. Proc Natl Acad Sci 111: E3091-E3100.

Lehmann S, Stiehl DP, Honer M, Dominietto M, Keist R, Kotevic I, Wollenick K, Ametamey S, Wenger RH, Rudin M. 2009. Longitudinal and multimodal in vivo imaging of tumor hypoxia and its downstream molecular events. Proc Natl Acad Sci 106: 14004-14009.

Li Z, Bao S, Wu Q, Wang H, Eyler C, Sathornsumetee S, Shi Q, Cao Y, Lathia J, McLendon RE, et al. 2009. Hypoxiainducible factors regulate tumorigenic capacity of glioma stem cells. Cancer Cell 15: 501-513.

Lin EY, Nguyen AV, Russell RG, Pollard JW. 2001. Colonystimulating factor 1 promotes progression of mammary tumors to malignancy. J Exp Med 193: 727-740.

Lowenfels AB, Maisonneuve P, Cavallini G, Ammann RW, Lankisch PG, Andersen JR, Dimagno EP, Andren-Sandberg A, Domellof L. 1993. Pancreatitis and the risk of pancreatic cancer. N Engl J Med 328: 1433-1437.

Lu P, Weaver VM, Werb Z. 2012. The extracellular matrix: A dynamic niche in cancer progression. J Cell Biol 196: 395-406.

MacLaurin J, Chapman J, Jones GW, Roose T. 2012. The buckling of capillaries in solid tumours. Proc Math Phys Eng Sci 468: rspa20120418.

Maes H, Kuchnio A, Peric A, Moens S, Nys K, De Bock K, Quaegebeur A, Schoors S, Georgiadou M, Wouters J, et al. 2014. Tumor vessel normalization by chloroquine independent of autophagy. Cancer Cell 26: 190-206.

Magee JA, Piskounova E, Morrison SJ. 2012. Cancer stem cells: Impact, heterogeneity, and uncertainty. Cancer Cell 21: $283-296$.

Mantovani A. 2010. Molecular pathways linking inflammation and cancer. Curr Mol Med 10: 369-373.

Martin GR, Jain RK. 1994. Noninvasive measurement of interstitial $\mathrm{pH}$ profiles in normal and neoplastic tissue using fluorescence ratio imaging microscopy. Cancer Res 54: 5670-5674.

Martinez-Zaguilan R, Seftor EA, Seftor RE, Chu YW, Gillies RJ, Hendrix MJ. 1996. Acidic pH enhances the invasive behavior of human melanoma cells. Clin Exp Metastasis 14: $176-186$.

Marusyk A, Almendro V, Polyak K. 2012. Intra-tumour heterogeneity: A looking glass for cancer? Nat Rev Cancer 12: 323-334.

Marusyk A, Tabassum DP, Altrock PM, Almendro V, Michor F, Polyak K. 2014. Non-cell-autonomous driving of tu- 
mour growth supports sub-clonal heterogeneity. Nature 514: $54-58$.

Matus DQ, Lohmer LL, Kelley LC, Schindler AJ, Kohrman AQ, Barkoulas M, Zhang W, Chi Q, Sherwood DR. 2015. Invasive cell fate requires $\mathrm{G}_{1}$ cell-cycle arrest and histone deacetylase-mediated changes in gene expression. Dev Cell 35: 162-174.

Mayer A, Wree A, Höckel M, Leo C, Pilch H, Vaupel P. 2004. Lack of correlation between expression of HIF- $1 \alpha$ protein and oxygenation status in identical tissue areas of squamous cell carcinomas of the uterine cervix. Cancer Res 64: 5876-5881.

Mazzone M, Dettori D, de Oliveira RL, Loges S, Schmidt T, Jonckx B, Tian YM, Lanahan AA, Pollard P, de Almodovar CR, et al. 2009. Heterozygous deficiency of PHD2 restores tumor oxygenation and inhibits metastasis via endothelial normalization. Cell 136: 839-851.

McKay RR, Rodriguez GE, Lin X, Kaymakcalan MD, Hamnvik OP, Sabbisetti VS, Bhatt RS, Simantov R, Choueiri TK. 2015. Angiotensin system inhibitors and survival outcomes in patients with metastatic renal cell carcinoma. Clin Cancer Res 21: 2471-2479.

Menter AR, Carroll N, Delate T, Hornbrook MC, Kushi LH, Sakoda L, Lee VS, Quinn VP, Adams JL, Ritzwoller DP. 2014. Effect of angiotensin system inhibitors on survival in patients receiving chemotherapy for advanced nonsmall cell lung cancer. 2014 ASCO Annual Meeting. Chicago, IL, May 30-June 3.

Mohyeldin A, Garzon-Muvdi T, Quinones-Hinojosa A. 2010. Oxygen in stem cell biology: A critical component of the stem cell niche. Cell Stem Cell 7: 150-161.

Morita T. 1995. Low $\mathrm{pH}$ leads to sister-chromatid exchanges and chromosomal aberrations, and its clastogenicity is Sdependent. Mutat Res 334: 301-308.

Motz GT, Coukos G. 2013. Deciphering and reversing tumor immune suppression. Immunity 39: 61-73.

Movahedi K, Guilliams M, Van den Bossche J, Van den Bergh R, Gysemans C, Beschin A, De Baetselier P, Van Ginderachter JA. 2008. Identification of discrete tumorinduced myeloid-derived suppressor cell subpopulations with distinct T cell-suppressive activity. Blood 111: 4233 4244.

Movsas B, Chapman JD, Hanlon AL, Horwitz EM, Greenberg RE, Stobbe C, Hanks GE, Pollack A. 2002. Hypoxic prostate $/$ muscle $\mathrm{pO}_{2}$ ratio predicts for biochemical failure in patients with prostate cancer: Preliminary findings. Urology 60: 634-639.

Mpekris F, Angeli S, Pirentis AP, Stylianopoulos T. 2015 Stress-mediated progression of solid tumors: Effect of mechanical stress on tissue oxygenation, cancer cell proliferation, and drug delivery. Biomech Model Mechanobiol 14: $1391-1402$.

Nagy JA, Benjamin L, Zeng H, Dvorak AM, Dvorak HF. 2008. Vascular permeability, vascular hyperpermeability and angiogenesis. Angiogenesis 11: 109-119.

Nagy JA, Chang SH, Shih SC, Dvorak AM, Dvorak HF. 2010. Heterogeneity of the tumor vasculature. In Seminars in thrombosis and hemostasis, Vol. 36, pp. 321-331. Thieme Medical, New York.

Nakai Y, Isayama H, Ijichi H, Sasaki T, Sasahira N, Hirano K, Kogure H, Kawakubo K, Yagioka H, Yashima Y, et al. 2010. Inhibition of renin-angiotensin system affects prognosis of advanced pancreatic cancer receiving gemcitabine. Br J Cancer 103: 1644-1648.

Nakai Y, Isayama H, Sasaki T, Takahara N, Saito K, Ishigaki K, Hamada T, Mizuno S, Miyabayashi K, Yamamoto K, et al. 2015. The inhibition of renin-angiotensin system in advanced pancreatic cancer: An exploratory analysis in 349 patients. J Cancer Res Clin Oncol 141: 933-939.

Naxerova K, Jain RK. 2015. Using tumour phylogenetics to identify the roots of metastasis in humans. Nat Rev Clin Oncol 12: 258-272.

Naxerova K, Brachtel E, Salk JJ, Seese AM, Power K, Abbasi B, Snuderl M, Chiang S, Kasif S, Jain RK. 2014. Hypermutable DNA chronicles the evolution of human colon cancer. Proc Natl Acad Sci 111: E1889-E1898.

Neri D, Supuran CT. 2011. Interfering with $\mathrm{pH}$ regulation in tumours as a therapeutic strategy. Nat Rev Drug Discov 10: 767-777.

Netti PA, Roberge S, Boucher Y, Baxter LT, Jain RK. 1996. Effect of transvascular fluid exchange on pressure-flow relationship in tumors: A proposed mechanism for tumor blood flow heterogeneity. Microvasc Res 52: 27-46.

Netti PA, Berk DA, Swartz MA, Grodzinsky AJ, Jain RK. 2000. Role of extracellular matrix assembly in interstitia transport in solid tumors. Cancer Res 60: 2497-2503.

Noman MZ, Desantis G, Janji B, Hasmim M, Karray S, Dessen P, Bronte V, Chouaib S. 2014. PD-L1 is a novel direct target of HIF- $1 \alpha$, and its blockade under hypoxia enhanced MDSC-mediated T cell activation. J Exp Med 211: 781-790.

Noman MZ, Hasmim M, Messai Y, Terry S, Kieda C, Janji B, Chouaib S. 2015. Hypoxia: A key player in antitumor immune response. A review in the theme: Cellular responses to hypoxia. Am J Physiol Cell Physiol 309: C569-C579.

Nordsmark M, Bentzen SM, Rudat V, Brizel D, Lartigau E, Stadler P, Becker A, Adam M, Molls M, Dunst J, et al. 2005. Prognostic value of tumor oxygenation in 397 head and neck tumors after primary radiation therapy. An international multi-center study. Radiother Oncol 77: $18-24$.

Noy R, Pollard JW. 2014. Tumor-associated macrophages: From mechanisms to therapy. Immunity 41: 49-61.

Ohlund D, Elyada E, Tuveson D. 2014. Fibroblast heterogeneity in the cancer wound. J Exp Med 211: 1503-1523.

Orimo A, Gupta PB, Sgroi DC, Arenzana-Seisdedos F, Delaunay T, Naeem R, Carey VJ, Richardson AL, Weinberg RA. 2005. Stromal fibroblasts present in invasive human breast carcinomas promote tumor growth and angiogenesis through elevated SDF-1/CXCL12 secretion. Cell 121: 335-348.

Overgaard J, Eriksen JG, Nordsmark M, Alsner J, Horsman MR, Danish H, Neck Cancer Study G. 2005. Plasma osteopontin, hypoxia, and response to the hypoxia sensitiser nimorazole in radiotherapy of head and neck cancer: results from the DAHANCA 5 randomised double-blind placebo-controlled trial. Lancet Oncol 6: 757-764.

Ozdemir BC, Pentcheva-Hoang T, Carstens JL, Zheng X, Wu CC, Simpson TR, Laklai H, Sugimoto H, Kahlert C, Novitskiy SV, et al. 2014. Depletion of carcinoma-associated fibroblasts and fibrosis induces immunosuppression and accelerates pancreas cancer with reduced survival. Cancer Cell 25: 719-734. 
J.D. Martin et al.

Padera TP, Kadambi A, di Tomaso E, Carreira CM, Brown EB, Boucher Y, Choi NC, Mathisen D, Wain J, Mark EJ, et al. 2002. Lymphatic metastasis in the absence of functional intratumor lymphatics. Science 296: 1883-1886.

Padera TP, Stoll BR, Tooredman JB, Capen D, di Tomaso E, Jain RK. 2004. Pathology: Cancer cells compress intratumour vessels. Nature 427: 695 .

Padera TP, Meijer EF, Munn LL. 2016. The lymphatic system in disease processes and cancer progression. Annu Rev Biomed Eng 18: 125-158.

Palumbo A, Da Costa Nde O, Bonamino MH, Pinto LFR, Nasciutti LE. 2015. Genetic instability in the tumor microenvironment: A new look at an old neighbor. $\mathrm{Mol}$ Cancer 14: 1.

Papageorgis P, Stylianopoulos T. 2015. Role of TGF $\beta$ in regulation of the tumor microenvironment and drug delivery (review). Int J Oncol 46: 933-943.

Paszek MJ, DuFort CC, Rossier O, Bainer R, Mouw JK, Godula K, Hudak JE, Lakins JN, Wijekoon AC, Cassereau L, et al. 2014. The cancer glycocalyx mechanically primes integrin-mediated growth and survival. Nature 511: 319-325.

Patenaude A, Woerher S, Umlandt P, Wong F, Ibrahim R, Kyle A, Unger S, Fuller M, Parker J, Minchinton A. 2015 A novel population of local pericyte precursor cells in tumor stroma that require Notch signaling for differentiation. Microvasc Res 101: 38-47.

Philip B, Ito K, Moreno-Sanchez R, Ralph SJ. 2013. HIF expression and the role of hypoxic microenvironments within primary tumours as protective sites driving cancer stem cell renewal and metastatic progression. Carcinogenesis 34: 1699-1707.

Pickup M, Novitskiy S, Moses HL. 2013. The roles of TGF $\beta$ in the tumour microenvironment. Nat Rev Cancer 13: 788-799.

Pirentis AP, Polydorou C, Papageorgis P, Voutouri C, Mpekris F, Stylianopoulos T. 2015. Remodeling of extracellular matrix due to solid stress accumulation during tumor growth. Connect Tissue Res 56: 345-354.

Plaks V, Kong N, Werb Z. 2015. The cancer stem cell niche: How essential is the niche in regulating stemness of tumor cells? Cell Stem Cell 16: 225-238.

Provenzano PP, Cuevas C, Chang AE, Goel VK, Von Hoff DD, Hingorani SR. 2012. Enzymatic targeting of the stroma ablates physical barriers to treatment of pancreatic ductal adenocarcinoma. Cancer Cell 21: 418-429.

Pugh CW, Ratcliffe PJ. 2003. Regulation of angiogenesis by hypoxia: Role of the HIF system. Nat Med 9: 677-684.

Raza A, Franklin MJ, Dudek AZ. 2010. Pericytes and vessel maturation during tumor angiogenesis and metastasis. Am J Hematol 85: 593-598.

Regan DP, Guth AM, Hansen RJ, Gustafson DL, Dow SW 2016. Angiotensin II type 1 receptor antagonism suppresses tumor metastasis through inhibition of CCL2CCR2 mediated monocyte recruitment. Cancer Immuno Res 4: A161-A161.

Rhim AD, Oberstein PE, Thomas DH, Mirek ET, Palermo CF, Sastra SA, Dekleva EN, Saunders T, Becerra CP, Tattersall IW, et al. 2014. Stromal elements act to restrain, rather than support, pancreatic ductal adenocarcinoma. Cancer Cell 25: 735-747.
Ricci-Vitiani L, Pallini R, Biffoni M, Todaro M, Invernici G, Cenci T, Maira G, Parati EA, Stassi G, Larocca LM, et al. 2010. Tumour vascularization via endothelial differentiation of glioblastoma stem-like cells. Nature 468: 824828.

Riemann A, Wussling H, Loppnow H, Fu H, Reime S, Thews O. 2016. Acidosis differently modulates the inflammatory program in monocytes and macrophages. Biochim Biophys Acta 1862: 72-81.

Rivera LB, Bergers G. 2015. Cancer. Tumor angiogenesis, from foe to friend. Science 349: 694-695.

Robinson SC, Scott KA, Wilson JL, Thompson RG, Proudfoot AE, Balkwill FR. 2003. A chemokine receptor antagonist inhibits experimental breast tumor growth. Cancer Res 63: 8360-8365.

Ronnov-Jessen L, Petersen OW, Bissell MJ. 1996. Cellular changes involved in conversion of normal to malignant breast: Importance of the stromal reaction. Physiol Rev 76: $69-125$.

Ropponen K, Tammi M, Parkkinen J, Eskelinen M, Tammi R, Lipponen P, Ågren U, Alhava E, Kosma VM. 1998. Tumor cell-associated hyaluronan as an unfavorable prognostic factor in colorectal cancer. Cancer Res 58: 342-347.

Sadeghi N, Abbruzzese JL, Yeung SCJ, Hassan M, Li D. 2012. Metformin use is associated with better survival of diabetic patients with pancreatic cancer. Clin Cancer Res 18: 2905-2912.

Samani A, Zubovits J, Plewes D. 2007. Elastic moduli of normal and pathological human breast tissues: An inversion-technique-based investigation of 169 samples. Phys Med Biol 52: 1565-1576.

Sauvant C, Nowak M, Wirth C, Schneider B, Riemann A, Gekle M, Thews O. 2008. Acidosis induces multi-drug resistance in rat prostate cancer cells (AT1) in vitro and in vivo by increasing the activity of the p-glycoprotein via activation of p38. Int J Cancer 123: 2532-2542.

Scherz-Shouval R, Santagata S, Mendillo ML, Sholl LM, Ben-Aharon I, Beck AH, Dias-Santagata D, Koeva M, Stemmer SM, Whitesell L, et al. 2014. The reprogramming of tumor stroma by HSF1 is a potent enabler of malignancy. Cell 158: 564-578.

Semenza GL. 2012. Molecular mechanisms mediating metastasis of hypoxic breast cancer cells. Trends Mol Med 18: 534-543.

Semenza GL. 2014. Oxygen sensing, hypoxia-inducible factors, and disease pathophysiology. Аnnu Rev Pathol 9: $47-71$.

Semenza GL. 2016. Dynamic regulation of stem cell specification and maintenance by hypoxia-inducible factors. Mol Aspects Med 47-48: 15-23.

Sevick EM, Jain RK. 1989. Viscous resistance to blood flow in solid tumors: Effect of hematocrit on intratumor blood viscosity. Cancer Res 49: 3513-3519.

Sherman MH, Yu RT, Engle DD, Ding N, Atkins AR, Tiriac $\mathrm{H}$, Collisson EA, Connor F, Van Dyke T, Kozlov S, et al. 2014. Vitamin D receptor-mediated stromal reprogramming suppresses pancreatitis and enhances pancreatic cancer therapy. Cell 159: 80-93. 
Shweiki D, Itin A, Soffer D, Keshet E. 1992. Vascular endothelial growth factor induced by hypoxia may mediate hypoxia-initiated angiogenesis. Nature 359: 843-845.

Singhal PK, Sassi S, Lan L, Au P, Halvorsen SC, Fukumura D, Jain RK, Seed B. 2016. Mouse embryonic fibroblasts exhibit extensive developmental and phenotypic diversity. Proc Natl Acad Sci 113: 122-127.

Sledge GW. 2015. Anti-vascular endothelial growth factor therapy in breast cancer: Game over? J Clin Oncol 33: $133-135$.

Soda Y, Marumoto T, Friedmann-Morvinski D, Soda M, Liu F, Michiue H, Pastorino S, Yang M, Hoffman RM, Kesari S. 2011. Transdifferentiation of glioblastoma cells into vascular endothelial cells. Proc Natl Acad Sci 108: 4274-4280.

Sorensen AG, Batchelor TT, Zhang WT, Chen PJ, Yeo P, Wang M, Jennings D, Wen PY, Lahdenranta J, Ancukiewicz M, et al. 2009. A "vascular normalization index" as potential mechanistic biomarker to predict survival after a single dose of cediranib in recurrent glioblastoma patients. Cancer Res 69: 5296-5300.

Sorensen AG, Emblem KE, Polaskova P, Jennings D, Kim H, Ancukiewicz M, Wang M, Wen PY, Ivy P, Batchelor TT, et al. 2012. Increased survival of glioblastoma patients who respond to antiangiogenic therapy with elevated blood perfusion. Cancer Res 72: 402-407.

Spivak-Kroizman TR, Hostetter G, Posner R, Aziz M, Hu C, Demeure MJ, Von Hoff D, Hingorani SR, Palculict TB, Izzo J, et al. 2013. Hypoxia triggers hedgehog-mediated tumor-stromal interactions in pancreatic cancer. Cancer Res 73: 3235-3247.

Stylianopoulos T, Jain RK. 2013. Combining two strategies to improve perfusion and drug delivery in solid tumors. Proc Natl Acad Sci 110: 18632-18637.

Stylianopoulos T, Martin JD, Chauhan VP, Jain SR, Diop-Frimpong B, Bardeesy N, Smith BL, Ferrone CR, Hornicek FJ, Boucher Y, et al. 2012. Causes, consequences, and remedies for growth-induced solid stress in murine and human tumors. Proc Natl Acad Sci 109: 15101-15108.

Stylianopoulos T, Martin JD, Snuderl M, Mpekris F, Jain SR, Jain RK. 2013. Coevolution of solid stress and interstitial fluid pressure in tumors during progression: Implications for vascular collapse. Cancer Res 73: 3833-3841.

Sugimoto H, Mundel TM, Kieran MW, Kalluri R. 2006. Identification of fibroblast heterogeneity in the tumor microenvironment. Cancer Biol Ther 5: 1640-1646.

Tabassum DP, Polyak K. 2015. Tumorigenesis: It takes a village. Nat Rev Cancer 15: 473-483.

Taghian AG, Abi-Raad R, Assaad SI, Casty A, Ancukiewicz M, Yeh E, Molokhia P, Attia K, Sullivan T, Kuter I, et al. 2005. Paclitaxel decreases the interstitial fluid pressure and improves oxygenation in breast cancers in patients treated with neoadjuvant chemotherapy: Clinical implications. J Clin Oncol 23: 1951-1961.

Tan E, Yan M, Campo L, Han C, Takano E, Turley H, Candiloro I, Pezzella F, Gatter K, Millar E. 2009. The key hypoxia regulated gene CAIX is upregulated in basallike breast tumours and is associated with resistance to chemotherapy. Br J Cancer 100: 405-411.
Thiery JP, Acloque H, Huang RY, Nieto MA. 2009. Epithelial-mesenchymal transitions in development and disease. Cell 139: 871-890.

Thomlinson R, Gray L. 1955. The histological structure of some human lung cancers and the possible implications for radiotherapy. Br J Cancer 9: 539.

Tlsty TD, Coussens LM. 2006. Tumor stroma and regulation of cancer development. Annu Rev Pathol 1: 119-150.

Tolaney SM, Boucher Y, Duda DG, Martin JD, Seano G, Ancukiewicz M, Barry WT, Goel S, Lahdenrata J, Isakoff SJ, et al. 2015. Role of vascular density and normalization in response to neoadjuvant bevacizumab and chemotherapy in breast cancer patients. Proc Natl Acad Sci 112: $14325-14330$.

Tse JM, Cheng G, Tyrrell JA, Wilcox-Adelman SA, Boucher Y, Jain RK, Munn LL. 2012. Mechanical compression drives cancer cells toward invasive phenotype. Proc Natl Acad Sci 109: 911-916.

Tung JC, Barnes JM, Desai SR, Sistrunk C, Conklin MW, Schedin P, Eliceiri KW, Keely PJ, Seewaldt VL, Weaver VM. 2015. Tumor mechanics and metabolic dysfunction. Free Radic Biol Med 79: 269-280.

Vander Heiden MG, Cantley LC, Thompson CB. 2009. Understanding the Warburg effect: The metabolic requirements of cell proliferation. Science 324: 1029-1033.

Van der Veldt AA, Lubberink M, Bahce I, Walraven M, de Boer MP, Greuter HN, Hendrikse NH, Eriksson J, Windhorst AD, Postmus PE, et al. 2012. Rapid decrease in delivery of chemotherapy to tumors after anti-VEGF therapy: Implications for scheduling of anti-angiogenic drugs. Cancer Cell 21: 82-91.

van Malenstein $\mathrm{H}$, Gevaert O, Libbrecht L, Daemen A, Allemeersch J, Nevens F, Van Cutsem E, Cassiman D, De Moor B, Verslype C, et al. 2010. A seven-gene set associated with chronic hypoxia of prognostic importance in hepatocellular carcinoma. Clin Cancer Res 16: 42784288.

Vasudev NS, Reynolds AR. 2014. Anti-angiogenic therapy for cancer: Current progress, unresolved questions and future directions. Angiogenesis 17: 471-494.

Vaupel P, Mayer A. 2014. Hypoxia in tumors: Pathogenesisrelated classification, characterization of hypoxia subtypes, and associated biological and clinical implications. In Oxygen transport to tissue XXXVI, pp. 19-24. Springer, New York.

Vaupel P, Höckel M, Mayer A. 2007. Detection and characterization of tumor hypoxia using $\mathrm{pO}_{2}$ histography. Antioxid Redox Signal 9: 1221-1236.

Von Hoff DD, Ervin T, Arena FP, Chiorean EG, Infante J, Moore M, Seay T, Tjulandin SA, Ma WW, Saleh MN, et al. 2013. Increased survival in pancreatic cancer with nabpaclitaxel plus gemcitabine. $N$ Engl J Med 369: 16911703.

Wang R, Chadalavada K, Wilshire J, Kowalik U, Hovinga KE, Geber A, Fligelman B, Leversha M, Brennan C, Tabar V. 2010. Glioblastoma stem-like cells give rise to tumour endothelium. Nature 468: 829-833.

Ward PS, Thompson CB. 2012. Metabolic reprogramming: A cancer hallmark even Warburg did not anticipate. Cancer Cell 21: 297-308. 
J.D. Martin et al.

Whatcott CJ, Diep CH, Jiang P, Watanabe A, LoBello J, Sima C, Hostetter G, Shepard HM, Von Hoff DD, Han H. 2015a. Desmoplasia in primary tumors and metastatic lesions of pancreatic cancer. Clin Cancer Res 21: $3561-$ 3568.

Whatcott CJ, Han H, Von Hoff DD. 2015b. Orchestrating the tumor microenvironment to improve survival for patients with pancreatic cancer: Normalization, not destruction. Cancer J 21: 299-306.

Wilop S, von Hobe S, Crysandt M, Esser A, Osieka R, Jost E. 2009. Impact of angiotensin I converting enzyme inhibitors and angiotensin II type 1 receptor blockers on survival in patients with advanced non-small-cell lung cancer undergoing first-line platinum-based chemotherapy. J Cancer Res Clin Oncol 135: 1429-1435.

Wilson WR, Hay MP. 2011. Targeting hypoxia in cancer therapy. Nat Rev Cancer 11: 393-410.

Winkler F, Kozin SV, Tong RT, Chae SS, Booth MF, Garkavtsev I, Xu L, Hicklin DJ, Fukumura D, di Tomaso E, et al. 2004. Kinetics of vascular normalization by VEGFR2 blockade governs brain tumor response to radiation: Role of oxygenation, angiopoietin-1, and matrix metalloproteinases. Cancer Cell 6: 553-563.

Wojtkowiak JW, Rothberg JM, Kumar V, Schramm KJ, Haller E, Proemsey JB, Lloyd MC, Sloane BF, Gillies RJ. 2012. Chronic autophagy is a cellular adaptation to tumor acidic pH microenvironments. Cancer Res 72: 3938-3947.

Wong P-P, Demircioglu F, Ghazaly E, Alrawashdeh W, Stratford MR, Scudamore CL, Cereser B, Crnogorac-Jurcevic T, McDonald S, Elia G. 2015. Dual-action combination therapy enhances angiogenesis while reducing tumor growth and spread. Cancer Cell 27: 123-137.
Wrzesinski SH, Wan YY, Flavell RA. 2007. Transforming growth factor- $\beta$ and the immune response: Implications for anticancer therapy. Clin Cancer Res 13: $5262-$ 5270.

Yan M, Rayoo M, Takano E, Thorne H, Fox S. 2009. BRCA1 tumours correlate with a HIF- $1 \alpha$ phenotype and have a poor prognosis through modulation of hydroxylase enzyme profile expression. Br J Cancer 101: $1168-1174$.

Yang SX, Steinberg SM, Nguyen D, Wu TD, Modrusan Z, Swain SM. 2008. Gene expression profile and angiogenic marker correlates with response to neoadjuvant bevacizumab followed by bevacizumab plus chemotherapy in breast cancer. Clin Cancer Res 14: 5893-5899.

Yuan F, Salehi HA, Boucher Y, Vasthare US, Tuma RF, Jain RK. 1994. Vascular permeability and microcirculation of gliomas and mammary carcinomas transplanted in rat and mouse cranial windows. Cancer Res 54: 45644568.

Zheng X, Carstens JL, Kim J, Scheible M, Kaye J, Sugimoto H, Wu CC, LeBleu VS, Kalluri R. 2015. Epithelial-tomesenchymal transition is dispensable for metastasis but induces chemoresistance in pancreatic cancer. Nature 527: 525-530.

Zlotek-Zlotkiewicz E, Monnier S, Cappello G, Le Berre M, Piel M. 2015. Optical volume and mass measurements show that mammalian cells swell during mitosis. J Cell Biol 211: 765-774.

Zustiak S, Nossal R, Sackett DL. 2014. Multiwell stiffness assay for the study of cell responsiveness to cytotoxic drugs. Biotechnol Bioeng 111: 396-403. 


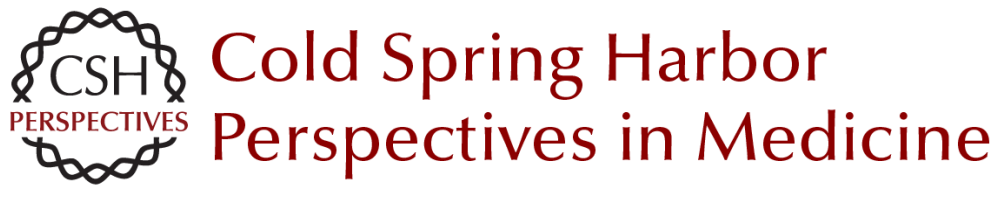

\title{
Reengineering the Tumor Microenvironment to Alleviate Hypoxia and Overcome Cancer Heterogeneity
}

\author{
John D. Martin, Dai Fukumura, Dan G. Duda, Yves Boucher and Rakesh K. Jain
}

Cold Spring Harb Perspect Med 2016; doi: 10.1101/cshperspect.a027094 originally published online September 23, 2016

\section{Subject Collection Cancer Evolution}

The Evolution and Ecology of Resistance in

Cancer Therapy

Robert A. Gatenby and Joel S. Brown

Big Bang Tumor Growth and Clonal Evolution Ruping Sun, Zheng Hu and Christina Curtis

Observing Clonal Dynamics across Spatiotemporal Axes: A Prelude to Quantitative Fitness Models for Cancer Andrew W. McPherson, Fong Chun Chan and Sohrab P. Shah

Evolution of Premalignant Disease Kit Curtius, Nicholas A. Wright and Trevor A. Graham

The Role of Aneuploidy in Cancer Evolution Laurent Sansregret and Charles Swanton

Treatment-Induced Mutagenesis and Selective Pressures Sculpt Cancer Evolution Subramanian Venkatesan, Charles Swanton, Barry S. Taylor, et al.

Chromosomal Instability as a Driver of Tumor Heterogeneity and Evolution Samuel F. Bakhoum and Dan Avi Landau

Coevolution of Leukemia and Host Immune Cells in Chronic Lymphocytic Leukemia

Noelia Purroy and Catherine J. Wu
The Evolution and Ecology of Resistance in Cancer Therapy

Robert Gatenby and Joel Brown

Phylogenetic Quantification of Intratumor Heterogeneity

Thomas B.K. Watkins and Roland F. Schwarz

The "Achilles' Heel" of Cancer and Its Implications for the Development of Novel Immunotherapeutic Strategies

Kroopa Joshi, Benjamin M. Chain, Karl S. Peggs, et al.

Homeostasis Back and Forth: An Ecoevolutionary Perspective of Cancer David Basanta and Alexander R.A. Anderson

Principles of Reconstructing the Subclonal

Architecture of Cancers Stefan C. Dentro, David C. Wedge and Peter Van Loo

Tumor Microenvironment and Differential

Responses to Therapy Eishu Hirata and Erik Sahai

Order Matters: The Order of Somatic Mutations Influences Cancer Evolution David G. Kent and Anthony R. Green

The Cellular Origin and Evolution of Breast Cancer Mei Zhang, Adrian V. Lee and Jeffrey M. Rosen

For additional articles in this collection, see http://perspectivesinmedicine.cshlp.org/cgi/collection/ 